\title{
Cheap and Disposable Gold and Silver Electrodes: Trends in the Application of Compact Discs and Digital Versatile Discs for Electroanalytical Chemistry
}

\section{Kevin C. Honeychurch}

Centre for Research in Biosciences, Department of Applied Sciences, University of the

West of England, Frenchay Campus, Coldharbour Lane, Bristol, BS16 1QY, UK, kevin.honeychurch@uwe.ac.uk

\section{Highlights}

- Compact discs and digital versatile discs can be readily used to give cheap reproducible $\mathrm{Au}$ and $\mathrm{Ag}$ electrodes.

- Their fabrication and use in electroanalytical chemistry is reviewed.

- Applications, performance characteristics and construction details are reviewed.

\begin{abstract}
Increasingly more reports have focused on the use of digital versatile discs (DVDs) and compact discs (CDs) for the fabrication of electrodes. The majority of discs use Al to reflect the laser. However, a notable percentage utilise Au or Ag. This layer can be mechanically or chemically exposed allowing for the economic fabrication of
\end{abstract}


otherwise expensive $\mathrm{Ag}$ and $\mathrm{Au}$ electrodes. Cleaning steps are not required due to the layer's mirror like surface. Mass production of these discs means they are available, reproducible and disposable. Modifications can be made by laser, inkjet printing, etching or xurography. Self-assembled monolayers and the attachment of functional groups can also be made. This review (98 references and 5 figures) is divided into four sections. The first describes the development of these electrodes and their fabrication and modification. The next three sections focused on applications for the determination of metal ions, biomedical and environmental analysis.

Keywords: Silver; gold; DVD; CD; voltammetry; amperometry; heavy metals; biomedical; environmental; disposable

\section{Introduction}

Compact discs (CDs) and digital versatile discs (DVDs) are commonly available cheap and can be obtained from recycled material. They are produced in massive volumes with high precision. Their exact composition differs from manufacture to manufacture, however, they are generally fabricated from several layers principally a base polycarbonate layer, dye layer for data storage and a 40-100 nm thick metal reflective layer [1-3] (figure 1a). The metal layer is designed to reflect the laser back to the detector during writing and reading of the disc. The surface is characterised by concentric tracks ca. $0.4 \mu \mathrm{m}$ in width and $0.1 \mu \mathrm{m}$ deep, [4-7] separated by 1.3 $\mu \mathrm{m}$ [8] designed as a guide for the laser to follow. For the majority of discs, the metal layer is generally formed from $\mathrm{Al}$, but $\mathrm{Ag}$ or $\mathrm{Au}$ are also commonly used. The presence of this metal layer offers a number of attractive possibilities for electrochemical analysis. Aluminium exhibits relatively poor electroanalytical properties and is seldom used as an electrode material as it oxidises fairly rapidly resulting in poor conductivity. However, both $\mathrm{Ag}$ and $\mathrm{Au}$ are noted for their good electrochemical properties in a range of different applications. Nevertheless, their 
relative high costs and the extensive cleaning steps required for usage has detracted from their general acceptance. In their seminal work in 2000 Angus et al [9] showed the possibility of fabricating Au electrodes from CDs and showed this to be a simple and inexpensive alternative method for the fabrication of these electrodes $[7,10]$. The Ag or Au layer can be simply exposed either by mechanical delamination of the disc $[1,7]$ or by removal of the upper polymer layers with a suitable solvent such as nitric acid $[9,11]$. A single disc can be used to manufacture many electrodes at little cost $(<2$ Pence Sterling/electrode) tailored to various different geometries and configurations [12,13]. The mirror like nature of the exposed reflective metal layer elevates the need for any excessive polishing cleaning steps. The low cost the disc means they can be, if needed, treated as disposable one shot devices. Further modifications can also be made by techniques such as laser [14] and inkjet printing $[12,15,16]$ or by the heat transfer of toner masks [17-23] designs onto the metal surface. Other alternative methods for the economic fabrication of electrodes exist and have been widely used and reviewed, principally, screen-printed electrodes [24] and the application of metal wire based electrodes [25]. The technique of screen-printing is highly attractive for the mass production of electrodes of the same formulation and dimensions. However, it can be costly and time consuming if different designs and architectures are required and the reproducibility of electrodes constructed from metal wire can be difficult to control.

This present review is divided into five main sections. The first section is focused on the background regarding the development of these electrodes and describes methods used for their fabrication and modification. The next three sections then focused on the application of these devices for the determination of metal ions, and applications for biomedical and environmental analysis. This represents the first review in this area. 


\section{Fabrication Strategies}

Angnes et al [9] were the first to show the possibility of fabricating Au electrodes from compact discs. The technique they developed has now become the most commonly reported fabrication method. In their approach, the disc was cut into slices, in a similar manner to that of a "pizza". Concentrated nitric acid was then applied to remove the upper protective polymer coatings to expose the Au layer below. The removal of the protective coatings was reported to require only a few minutes and the remaining polymer material could be readily removed with a jet of water. Once removed the exposed Au layer can be then used as the working electrode. Using a similar fabrication technique, Richter et al [26] in their pioneering work in 2003, showed a number of new applications that these CD electrodes could be employed for; including the quantification of chloride ions by potentiometry by flow injection analysis, cyanide by amperometry flow injection analysis and $\mathrm{Pb}$ by square wave stripping voltammetry.

The majority of reports detail the fabrication and development of electrodes with dimensions in the $\mathrm{mm}$ to $\mathrm{cm}$ range. An interesting possibility investigated by Angnes et al [9] who have shown the possibility of developing electrodes with dimensions in the nm range. A number of analytical advantages can be gained through the use of working electrodes with these dimensions [27] and their investigations have shown the possibility of utilising the edge of the thin metal film of a $\mathrm{Au}$ recordable $\mathrm{CD}$ to form a $8 \mathrm{~mm}$ x $80 \mathrm{~nm}$ working electrode [9]. Linear sweep investigation showed typical nanoelectrode behaviour for ferrocyanide concentrations up to $9 \mathrm{mM}$ in $0.1 \mathrm{M} \mathrm{KCl}$ gaining a current density of $4 \mathrm{~A} / \mathrm{M} / \mathrm{cm}^{-2}$. However, the preparation of the electrode was reported to be problematic.

Alternative methods [7] have also been reported including the mechanical delamination of the disc. Figure $1 \mathrm{~b}$ shows the construction of this device. Sections 
of $10 \mathrm{~mm} \times 60 \mathrm{~mm}$ of the CD-R can be cut out with a suitable pair of scissors, and in this case, the upper Ag layer was then removed by slowly peeling it away from the lower polycarbonate substrate. A $10 \mathrm{~mm}$ x $30 \mathrm{~mm}$ section of this was then fixed with adhesive to a suitable section of polycarbonate substrate (base of compact disc) with the Ag layer now facing upwards. A section of dielectric (RS components) modified with a $5 \mathrm{~mm}$ diameter hole was placed over the exposed $\mathrm{Ag}$ layer to define the working electrode area. A strip of exposed Ag was left at the opposite end to be used as an electrical contact to the potentiostat.

(a)

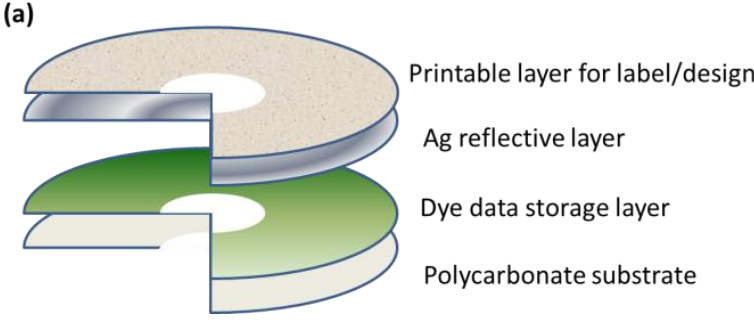



Figure 1. (a) Schematic of CD and (b) Ag CD electrode construction, after [7]. Alternatively, the metal layer can be removed by the application of sticky-backed plastic to top polymeric coatings of the disc [28]. The silver layer was then cut with scissors to an appropriate size and the surface area of the electrode was defined using a plastic hole-reinforcer (figure 2). This was then affixed to a piece of polycarbonate (base of compact disc) of the same size using electrical insulation tape. The remainder of the electrode was enclosed in electrical insulation tape, leaving an exposed pad at the opposite end for contact to be made to the potentiostat. Initial experiments utilised silver working electrodes with the area of the working electrode to be in contact with solution defined using electrical tape 
(RS Components) with a disc of approximately $5 \mathrm{~mm}$ diameter removed using a hole-punch. This aspect of fabrication was later improved by utilising plastic holereinforcers of $5 \mathrm{~mm}$ diameter. It should be noted, that care needs to be taken whilst manipulating the very thin metal layer once liberated from its polycarbonate due its poor mechanical properties.


Figure 2. Ag working electrode fabrication. (A) Removal of the silver layer was facilitated by sticky-backed plastic. (B) The silver layer was then cut to an appropriate size and the surface area of the electrode defined using a plastic holereinforcer and affixed to a piece of polycarbonate $(\mathrm{C})$ The remainder of the electrode was enclosed in electrical insulation tape and trimmed to yield the final product shown in figure $2[28]$.

The Au and Ag electrodes fabricated can be further modified via a number of different techniques such as that demonstrated by Daniel et al [29] who have used a laser printer to transfer a design onto wax paper which can be then heat-transfer onto the Au surface of a delaminated CD-R (Figure 5). The Au layer can then etched from the unprinted regions and the toner then removed with solvent to give the required designed. The resulting Au electrodes were then used as part of a conventional batch or flow cell system for the determination of dopamine. Microfluidic flow cells (7-12 $\mu \mathrm{m}$ interlayer gap) were fabricated using a gasket spacer of the desired shape drawn and laser printed and heat transferred onto the CD. A second $C D$ section was then heat-sealed on top of this to form the microfluidic flow cell. The overall internal volume was estimated to be $240 \mathrm{~nL}$, of 
which a layer of only approximately $15 \mathrm{~nL}$ was reported to be above each working electrode. The functionality of these electrodes as well as of the microfluidic flow cells was demonstrated by voltammetry and flow injection amperometric analysis. The repeatability of the device was investigated by recording the amperometric oxidation of dipyrone at $+0.800 \mathrm{~V}$ for sequential injections of $10 \mu \mathrm{L}$ of a $1.35 \mathrm{mM}$ dipyrone solution in $0.1 \mathrm{M}$ acetate buffer solution at a flow rate of $83 \mu \mathrm{L} / \mathrm{min}$. A relative standard deviation for the amperometric response was reported as $1.16 \%$ ( $\mathrm{n}=27$ ) with a calculated sampling frequency of $c a$. $40 / \mathrm{h}$.



A

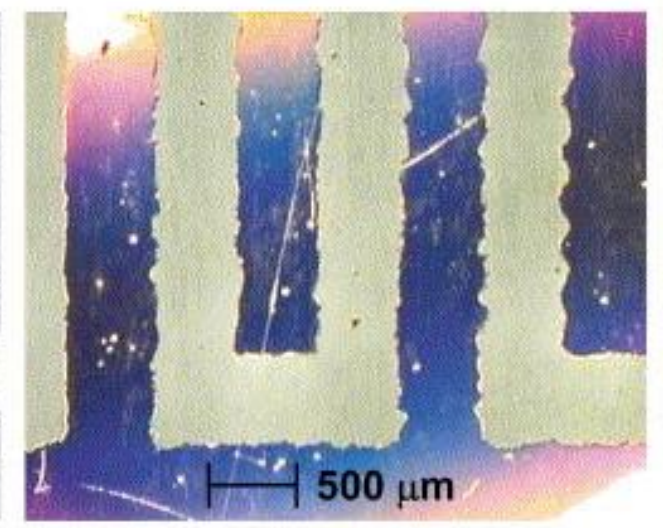

B

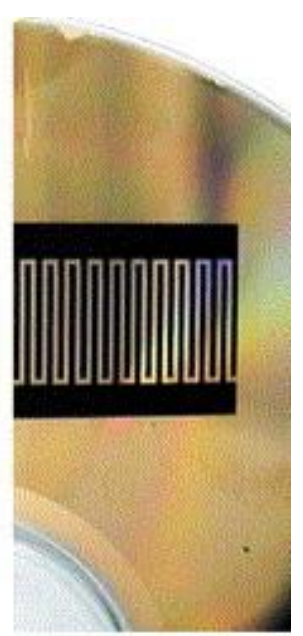

C

Figure 5. Construction of an interdigitated array of gold electrodes on a CD. (A) Magnification of a section after printing (by heat-transfer of toner mask), revealing the resolution of the lines defined by the toner. (B) Magnification of a section of the finished gold electrodes (after etching and toner removal). (C) Full view of the toner mask applied onto the CD. Reproduced from Daniel et al. [29] with permission from Elsevier B.V.

Ferreira et al [58] have utilised a similar approach for the determination dipyrone, along with $\mathrm{Pb} \mathrm{Cu}, \mathrm{Hg}$, paracetamol and nitrite. Interestingly, their investigation showed the possibility to use a permanent marker pen to define the electrode design on the Au CD-R after defining by laser jet printing. Paixão et al [18] have developed a twin-electrode thin-layer cell which was operated in the generator collector mode with reported collection efficiencies of $100 \%$ for the ferri/ferrocyanide redox couple. The thin layer cell was constructed from Au CDs 
to from two $500 \mu \mathrm{m}$ diameter working electrodes. These were place facing each other, separated by a layer of toner mask (6 $\mu \mathrm{m}$ thick). The thickness of the resulting thin layer cell could be controlled by the number of layers of toner mask deposited. The thin layer cell was then heat sealed and with two holes to form the inlet and outlet channels (0.8 $\mathrm{mm}$ diameter). It was shown that as a result of the fast transfer speeds of solutions within the thin-layer cell, electrochemical processes involving EC mechanisms could be investigated. This was demonstrated with ascorbic acid as an irreversible model system. Digital simulation was used to relate current at both electrodes (generator and collector) to the gap, flow rate and rate constant for a typical EC mechanism.

Ferreira et al [30] have used the same device to determine the diffusion coefficients of $\mathrm{Fe}(\mathrm{CN})_{6}{ }^{3-}, \mathrm{Ru}\left(\mathrm{NH}_{3}\right)_{6^{2+}}$, and quinone were determined in water and, for $\mathrm{Fe}(\mathrm{CN})_{6}{ }^{4-}$, in binary mixtures with glycerol. Measurements of the diffusion coefficients of ferrocene in micellar solutions of the cationic surfactant $\mathrm{CTABr}$ were also performed.

\section{Chemical Modifications}

The surface of the $\mathrm{Au} \mathrm{CD}$ electrode offers a number of possibilities for further chemical modifications. In one such investigation, Walcarius et al [31] have shown that by applying a suitable cathodic potential at a Au CD electrode in a surfactanthydrolysed sol solution it is possible to generate hydroxyl ions to catalyse the polycondensation of a self-assembled layer of hexagonally packed one-dimensional channels. These were shown to grow perpendicularly to the electrode surface and they could be controlled to deposition at heterogeneous supports. It was concluded that this process could be used for the design of complex patterns on the CD metal surface. Yu $[11,32]$ has investigated the possibility of forming self-assembled monolayers of long-chain alkane thiols such as $n-\mathrm{C}_{18} \mathrm{H}_{37} \mathrm{SH}$ adsorbed on $\mathrm{Au}$ CDs [32]. The results showed that there were no distinct differences in the quality and 
structure monolayers and self-assembled monolayers (SAMs) formed at the CDs than those formed on standard Au substrates.

Matemadombo et al [33] have shown that amine substituted cobalt phthalocyanine (CoTAPc) can be deposited on Au CD surfaces by using an interconnecting layer of a SAM of mercaptopropionic acid or Lomant's reagent (dithiobis(N-succinimidyl propionate). Electrochemical investigations showed near $100 \%$ surface coverage. SAM-CoTAPc layers were reported to show electro-catalytic activity for oxygen reduction through the Co(I) central metal ion. The modified electrode were reported to show good long term stability and promise as possible sensors.

Sibottier et al [34] have reported the development of an amine or thiol functionalised electro-generated sol-gel-derived silica film at a $\mathrm{Au} C D$ based electrode. The electrochemical deposition of this film as reported to be achieved by the formation of a so-called "nanoglue" on the electrode surface. Cathodic electrolysis was undertaken to form hydroxyl ions that catalysed the formation of organo-silica films. The electrodeposition process was reported to occur via two growth phases: an initial first slow stage resulting in rough homogeneous films with a thickness in the sub- $\mu \mathrm{m}$ range; followed by a faster gel forming step giving thicker films $(>1 \mu \mathrm{m})$ and rougher macro-porous deposits.

The possibility of modifying Au CD electrodes with poly(4-aminophenol) has been explored by Ferreira et al [35] with the aim of forming polymers capable of immobilizing purine bases and oligonucleotides. Enhanced electrochemical signals in the order of three and six fold for the electrochemical response of adenine and guanine were reported at the modified electrodes. Impedance studies indicated higher charge transfer impedance at the modified electrodes containing adenosine monophosphate. Investigations by atomic force microscopy indicated that the nitrogenated bases had a strong influence on the morphology of the modified electrode surface. Au electrodes were modified by first cleaning with piranha 
solution (concentrated $\mathrm{H}_{2} \mathrm{SO}_{4}(98 \%)$ and $\left.\mathrm{H}_{2} \mathrm{O}_{2}(30 \%), 3: 1 \mathrm{v} / \mathrm{v}\right)$ and washed with deionised water. The electrode was submitted to potential cycling in $0.10 \mathrm{M} \mathrm{H}_{2} \mathrm{SO}_{4}$ between $-0.20 \mathrm{~V}$ and $+1.50 \mathrm{~V}$ at a scan rate of $100 \mathrm{mV} / \mathrm{s}$. The Au electrode was then modified with poly(4-aminophenol) by continuous voltammetric cycling of between $0.00 \mathrm{~V}$ and $+1.50 \mathrm{~V}$ at $50 \mathrm{mV} / \mathrm{s}$ using a $25 \mathrm{mM}$ solution of 4-aminophenol in $0.50 \mathrm{M} \mathrm{H} \mathrm{H}_{2} \mathrm{SO}_{4}$. After this treatment, adenine, guanine, guanosine monophosphate (GMP) and adenosine monophosphate, and oligonucleotide were immobilized on the surface of the electrode by adsorption at room temperature.

Recently, Foguel et al [36] have explored the construction of Au electrodes using three kinds of Au CD-Rs (Inkjet MAM-A, MAM-A, and Archive MAM-A from CDMAM-A Inc. trade, Colorado, CO, USA). Following 4-6 minutes surface pretreatment with $0.2 \mathrm{M}$ sulphuric acid, contact angles and the cyclic voltammetric behaviour of the behaviour of the ferro/ferricyanide redox couple for the bare commercial $\mathrm{Au}$ electrode were reported to be very similar. The Au CD electrode surface was also treated after the removal of the upper polymeric film with concentrated nitric acid by electro-polishing in $1.0 \mathrm{M}$ sulphuric acid solution to reduce $\mathrm{Au}$ oxide present on the electrode surface. The electrochemical behaviour was found to be indicative of differences in physical parameters of the CD electrode surface. Whereas, differences in the original CD electrode surface were concluded to result in changes in the type of cyclic voltammograms obtained after cleaning with nitric acid. The authors also concluded from scanning tunnelling microscopy investigations that the $\mathrm{Au} C D$ surface is slightly more uniform than evaporated $\mathrm{Au}$ films. Further investigations by atomic force microscopy indicated that the lasertracks presented in Au layer varied in height from the peripheral to the central part of the CD-Rs. The authors concluded from these investigations of the different CD$\mathrm{R}$ that these were sufficiently similar as not to effect any subsequent modifications of the electrode. The possibility of immobilising onto the electrode surface an 
oligopeptide mimic of the active site of the acetylcholinesterase enzyme was then evaluated. The electrodes were shown to be suitable for immobilizing biological molecules and could be used as disposable transducers for the construction of biosensors.

\section{Applications}

\subsection{Metal Ion Analysis}

\subsubsection{Lead}

Stripping voltammetry is one of the most sensitive and economic methods for the determination of metal ions $[37,38]$. Detection limits in the low $\mu \mathrm{g} / \mathrm{L}$ region can be readily obtained with little sample pre-treatment or need for sophisticated laboratory equipment. Modern potentiostats are portable and can be operated on battery power alone allowing for analysis at the "point of care" or "in the field". Previously, stripping voltammetry at metal electrodes had been dominated by the use of Hg working electrodes. This lead to the method suffering from the perceived problems of toxicity and subsequent disposable issues led to a lack of market penetration. A number of different approaches have been made to overcome these issues, such as the use of less toxic metals and alloys; such as galinstan [39], Bi [40-42] and $\mathrm{Sb}$ [43] and alternative electrode materials such as screen-printed carbon [24]. Both Ag and Au electrodes have been used for some time in stripping voltammetry and offer a number of advantages in certain applications over other working electrode materials. However, the use of conventional $\mathrm{Ag}$ and $\mathrm{Au}$ electrodes has been hampered by the problems of expense and electrode fouling, requiring cleaning and extended preparation steps for their use. However, use of $\mathrm{CD}$ and DVD for the fabrication of $\mathrm{Ag}$ and Au electrodes overcomes many of these issues. Their cheap and ready available nature allows them to be treated as 
disposable, allowing them to be used once and then discarded overcoming problems of fouling and carry over.

Table 1 provides a summary of the reported applications of both CD and DVD derived electrodes for the determination of metal ions.

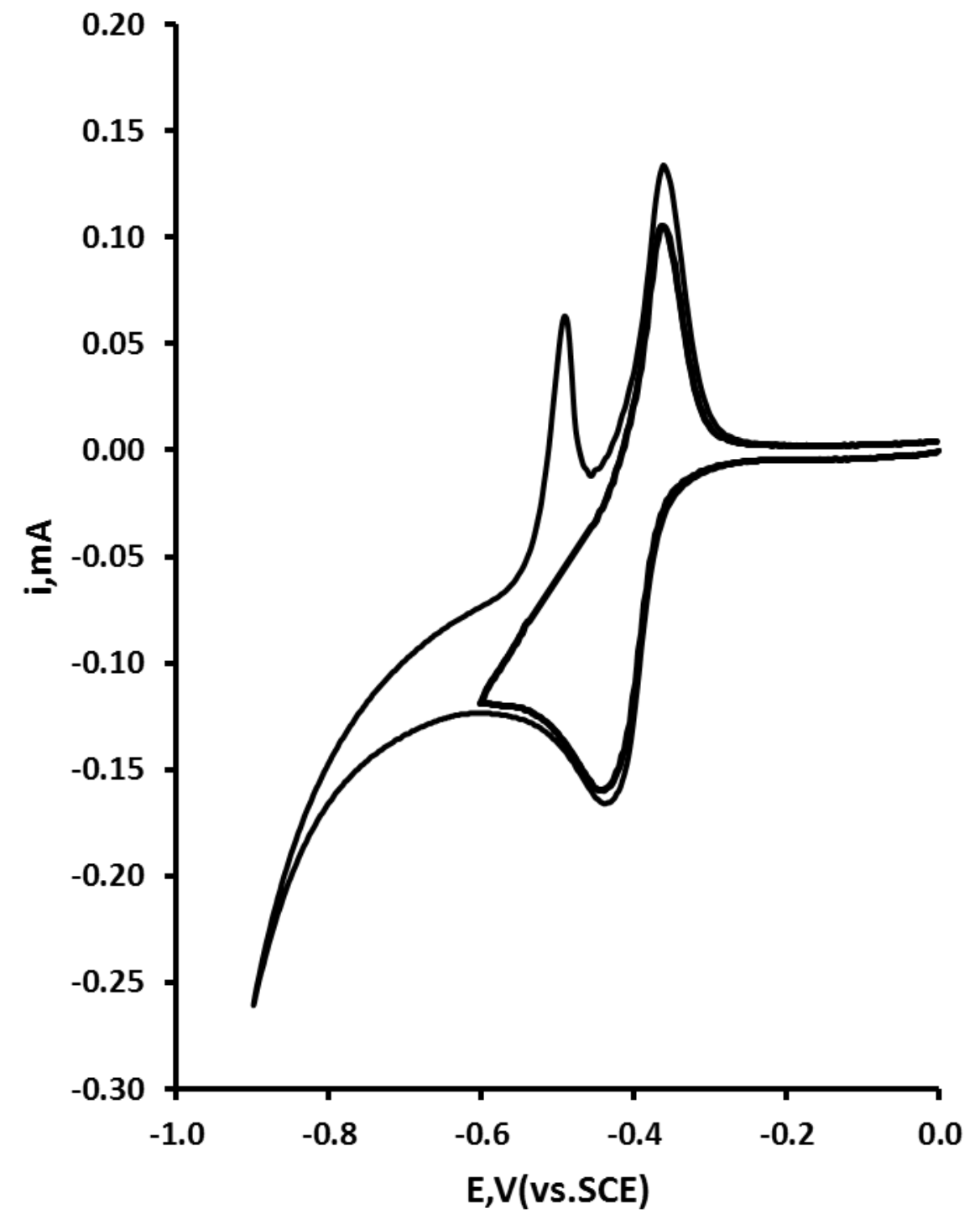

Figure 2. Typical cyclic voltammograms obtained in $0.1 \mathrm{M} \mathrm{HCl}$ containing $0.1 \mathrm{mM} \mathrm{Pb}$ at a Ag CD electrode, after [7].

Recently, the under potential deposition of $\mathrm{Pb}$ has been shown possible at a $\mathrm{Ag}$ electrode manufactured from a CD-R [7]. Cyclic voltammetric investigations in 0.1 $\mathrm{M} \mathrm{HCl}$ exhibited indicative of the over and underpotential of $\mathrm{Pb}$ at the electrode 
surface (figure 2) as previously shown by Richter et al [26]. Using a switching potential of $-0.9 \mathrm{~V}$ two stripping peaks where recorded at $-0.49 \mathrm{~V}$ and $-0.37 \mathrm{~V}(v s$. SCE) indicative of the stripping of the overpotential and underpotential multilayer and monolayers of $\mathrm{Pb}$ deposited on the electrode. Interestingly, this electrode showed very similar behaviour to that reported for conventional Ag electrodes [44]. Using underpotential deposition an anodic stripping voltammetry (ASV) method for the trace determination of $\mathrm{Pb}$ was developed. Using an accumulation time of $100 \mathrm{~s}$, a linear range of $20 \mathrm{ng} / \mathrm{mL}$ to $350 \mathrm{ng} / \mathrm{mL}$ was reported with a detection limit of 6 $\mathrm{ng} / \mathrm{mL}$. The method was successful applied for the determination of $\mathrm{Pb}^{2+}$ in roof water runoff.

Studies have also shown the possibility of utilising square wave stripping voltammetry for the determination of $\mathrm{Pb}[26]$ at Ag electrodes constructed from a CD-R. Utilising a supporting electrolyte of comprising of $0.1 \mathrm{M} \mathrm{NaNO}_{3}$ and $0.01 \mathrm{M}$ $\mathrm{HNO}_{3}$ and a more negative deposition potential of $-0.7 \mathrm{~V}$. Employing a deposition time of $180 \mathrm{~s}$ a detection limit of $0.2 \mathrm{ng} / \mathrm{mL}$ was obtained based on a signal to noise ratio of 3 . The stable reproducible nature of the developed device was demonstrated with a relative standard deviation (RSD) of $2.5 \%(n=20)$ being reported for the measurement of a $10 \mathrm{ng} / \mathrm{mL} \mathrm{Pb}$ solution.

The same authors [45] have employed a similar approach however, in this case, with a $\mathrm{Au}$ electrode fabricated from a $\mathrm{CD}-\mathrm{R}$ to determine $\mathrm{Pb}$ in rainwater using square wave anodic stripping voltammetry (SWASV). A detection limit of $80 \mathrm{ng} / \mathrm{L}$ was reported utilising a deposition time of $300 \mathrm{~s}$. The Au electrodes were prepared by removal of the polymeric layers with concentrated $\mathrm{HNO}_{3}$. The result exposed $\mathrm{Au}$ layer was then cut into $3 \times 40 \mathrm{~mm}$ slices and a ca. 2 or $3 \mathrm{~mm}^{2}$ working electrode area was then defined with enamel or PVC resin. An electrical contact was made by the attachment of a wire to the opposite end of the Au strip with Teflon tape. 
The authors also reported on the development of a specially designed miniature electrochemical cell which allowed for the use of high stirring speeds and small sample volumes. Investigations undertaken by the authors showed that the stripping behaviour of $\mathrm{Pb}$ and other metals at the $\mathrm{Au} C \mathrm{CD}-\mathrm{R}$ was best undertaken in a $\mathrm{Cl}^{-}$containing supporting electrolytes. The optimum supporting electrolyte was $\mathrm{HCl}$ at a concentration between $50 \mathrm{mM}$ and $300 \mathrm{mM}$. At higher $\mathrm{HCl}$ concentrations hydrogen gas evolution was reported which decrease the precision of the assay. The effect of deposition time was investigated over the range of 30 to $600 \mathrm{~s}$. The peak for a $7 \mu \mathrm{g} / \mathrm{L} \mathrm{Pb}$ solution was seen to increase nearly linearly with time up to $300 \mathrm{~s}$, beyond which it was found to plateau. Using the optimum conditions an RSD of $2.87 \%$ was obtained for 20 repetitive measurements of a $7 \mu \mathrm{g} / \mathrm{L} \mathrm{Pb}$ solution. Four different rainwater samples were fortified with $4.8 \mu \mathrm{g} / \mathrm{L} \mathrm{Pb}$ and a mean recovery of $103 \%$ was reported. Further analysis of ten rainwater samples collected in Sao Paulo city, between January and May 2000 showed the concentrations of $\mathrm{Pb}$ to range from $0.25 \mu \mathrm{g} / \mathrm{L}$ to $2.99 \mu \mathrm{g} / \mathrm{L}$. Storage of the $\mathrm{Au}$ electrodes was found to detrimental to the SWASV determination of $\mathrm{Pb}$, presumed to result from the formation of oxidises on the electrode surface. It was found possible to overcome is issue by electrochemically cycling between 0.0 and $+1.2 \mathrm{~V}$ in $0.05 \mathrm{M}$ perchloric acid.

\subsubsection{Selenium}

The determination of trace Se levels at Au CD electrodes formed has been reported by Fernandes Pereira et al [46]. The Au electrode was prepared cutting a section of a $\mathrm{Au}$ recordable $\mathrm{CD}$. The $\mathrm{Au}$ layer of the $\mathrm{CD}$ was exposed using concentrated $\mathrm{HNO}_{3}$ to remove its protective film. Two areas were exposed; one to form the electrical contact and other as the working electrode. 
In acidic solutions $\mathrm{Se}$ is present as selenous acid, $\mathrm{H}_{2} \mathrm{SeO}_{3}$ which can be electrochemically reduced through a $6 \mathrm{e}^{-}, 6 \mathrm{H}^{+}$process to form hydrogen selenide (eq.1) $\left(\mathrm{H}_{2} \mathrm{Se}\right)$ or several intermetallic species with the $\mathrm{Au}$ working electrode of various stoichiometries (eq.2).

$$
\begin{aligned}
& \mathrm{H}_{2} \mathrm{SeO}_{3}+6 \mathrm{H}^{+}+6 \mathrm{e}^{-} \rightarrow \mathrm{H}_{2} \mathrm{Se}+3 \mathrm{H}_{2} \mathrm{O} \\
& \mathrm{H}_{2} \mathrm{SeO}_{3}+\mathrm{nAu}+4 \mathrm{H}^{+}+4 \mathrm{e}^{-} \rightarrow \mathrm{Au}_{\mathrm{n}} \mathrm{Se}+3 \mathrm{H}_{2} \mathrm{O}
\end{aligned}
$$

The formation of this intermetallic species can cause problems as can be difficult to fully remove between subsequent measurements. However, the disposable nature of disc based electrodes alleviates this issue as measurements can be made at fresh, clean electrode each time.

Using an accumulation potential of $+0.4 \mathrm{~V}$ the authors used the formation of these intermetallic species to accumulate $\mathrm{Se}$ at the $\mathrm{Au}$ electrode surface. The anodic stripping of these compounds resulted in several anodic stripping peaks with the stripping peak with a peak potential $(\mathrm{Ep})$ of $+1.1 \mathrm{~V}$ being shown to give a linear response over the range 0.5 to $291 \mathrm{ng} / \mathrm{mL}$ for $\mathrm{Se}(\mathrm{IV})$. Two more anodic voltammetric peaks were also recorded, with Eps of $+0.6 \mathrm{~V}$ and $+0.8 \mathrm{~V}$, but were found to be analytical inferior. Using the method of multiple standard addition an average recovery of $96.4 \%$ was reported for a $50 \mathrm{ng} / \mathrm{mL}$ Se(IV) solution.

\subsubsection{Mercury}

The electrochemical determination of $\mathrm{Hg}$ offers a number of analytical challenges. It is known to form amalgams with a number of metals, such as Au, leading to problems with sample carry over [47] as $\mathrm{Hg}$ can diffuse into the working electrode making it difficult to remove. Consequently, there is a need for good quality Au 
working electrodes which are cheap and potentially disposable for $\mathrm{Hg}$ determination to overcome such problems. To meet with these demands, a number of reports have been made utilising $\mathrm{CD}$ based Au electrodes [48] have determined $\mathrm{Hg}$ in Cod fish fillets, following acid digestion, at Au electrodes fabricated from CDRs by chronopotentiometric stripping analysis. The electrodes were prepared from Kodak Gold (code 1721745) CD-Rs using $\mathrm{HNO}_{3}$ to expose the Au surface to form a working with a diameter of $0.3 \mathrm{~cm}$ and an area of $0.070 \mathrm{~cm}^{2}$. The percentage recovery for a known amount of $\mathrm{Hg}$ introduced in the sample before digestion was reported to be $95.3 \%(n=4)$. After each experiment the Au working electrode was cleaned electrochemically in a solution of $0.2 \mathrm{M} \mathrm{H}_{2} \mathrm{SO}_{4}$ by applying a potential of $+1.5 \mathrm{~V}$ for $40 \mathrm{~s}$, followed by scanning the potential five times between -0.25 and $+1.5 \mathrm{~V}$ at a scan rate of $0.02 \mathrm{~V} / \mathrm{s}$. The electrodes were then thoroughly washed with bi-distilled water before being introduced to $10 \mathrm{~mL}$ of sample extract in $0.05 \mathrm{M} \mathrm{HCl}$. The working electrode potential was set at $+0.3 \mathrm{~V}$ for $180 \mathrm{~s}$ with stirring. The potential was then scanned in from $+0.3 \mathrm{~V}$ to $+0.7 \mathrm{~V}$ using a constant current of $+0.75 \mu \mathrm{A}$. The resulting signal was then background subtracted using the signal obtained from a $0.05 \mathrm{M} \mathrm{HCl}$ solution. The effect of various other metal ions on the stripping response of $\mathrm{Hg}$ was studied and concentration ratios of $25: 1$ of $\mathrm{Zn}^{2+}, \mathrm{Pb}^{2+}$, $\mathrm{Fe}^{2+}$ and $\mathrm{Mn}^{2+}$ were reported to have little effect on the $\mathrm{Hg}$ signal. However, the addition of $\mathrm{Cu}^{2+}$ at concentrations above $100 \mu \mathrm{g} / \mathrm{L}$ resulted in a detectable shoulder, at approximately $+0.45 \mathrm{~V}$, on the stripping peak response obtained for 20 $\mu \mathrm{g} / \mathrm{L} \mathrm{Hg}(+0.54 \mathrm{~V})$. Below this concentration ratio expectable results could still be obtained. Employing a deposition time of $600 \mathrm{~s}$ a detection limit of $0.30 \mu \mathrm{g} / \mathrm{L} \mathrm{Hg}$ was reported with a corresponding linear range from 1 to $10 \mu \mathrm{g} / \mathrm{L}$. Using a shorter deposition time of $180 \mathrm{~s}$, a linear range of 5 to $100 \mu \mathrm{g} / \mathrm{L}$ was reported. A RSD of $1.92 \%(n=6)$ was reported for a $\mathrm{Hg}$ concentration of $20 \mu \mathrm{g} / \mathrm{L}$. 
The possibility of determining both $\mathrm{Hg}$ and methyl-mercury $\left(\mathrm{CH}_{3} \mathrm{Hg}^{+}\right)$in synthetic oceanic water has been explored at a Au CD-R (Mitsui Gold Standard) based electrode by stripping chronopotentiometry [49]. A deposition potential of $+0.3 \mathrm{~V}$ was reported to be most suitable, as the majority of other metals were reported not to be accumulated under these conditions. The use of a low stripping current was found advantageous as it was demonstrated that when the oxidation current was increased linearly, the resulting signal decreased nearly exponentially. At $+0.3 \mathrm{~V}$, no interference was observed for the addition of $200 \mu \mathrm{g} / \mathrm{L}$ of $\mathrm{Cd}^{2+}, \mathrm{Pb}^{2+}, \mathrm{Mn}^{2+}, \mathrm{Ni}^{2+}$, $\mathrm{Co}^{2+}, \mathrm{Fe}^{3+}$ and $\mathrm{Cr}^{3+}$ to a solution containing $10 \mu \mathrm{g} / \mathrm{L}$ of $\mathrm{Hg}$. Copper was reported not interfere as its re-oxidation peak occurs around $+0.3 \mathrm{~V}$ and to interfere would have to be relatively high concentrations. An RSD of $1.4 \%(n=48)$ was reported for a solution containing $10 \mu \mathrm{g} / \mathrm{L}$ of $\mathrm{Hg}$ with a detection limit of $8 \mathrm{ng} / \mathrm{L}(\mathrm{s} / \mathrm{n}=3)$ calculated for a deposition time of $600 \mathrm{~s}$. A recovery of between $93 \%$ and $105 \%$ was obtained for five successive runs of a NIST river water sample spiked with 20 ng/L of Hg. Methyl-mercury analysis was undertaken on an aquarium water sample containing synthetic oceanic water fortified with $\mathrm{CH}_{3} \mathrm{Hg}^{+}$.

Angnes et al [9] have utilised the related technique of potentiometric stripping for the determination of $\mathrm{Cu}$ and $\mathrm{Hg}$ ions. The electrode was fabricated by removing the upper protective layer with nitric acid to expose the Au substrate layer. Using an accumulation time of $60 \mathrm{~s}$; deposition potential, $-0.1 \mathrm{~V}$ with a supporting electrolyte of $0.1 \mathrm{M} \mathrm{HCl}$ linear ranges of 5 to $60 \mu \mathrm{g} / \mathrm{L}$ and 10 to $120 \mu \mathrm{g} / \mathrm{L}$, for both $\mathrm{Cu}$ and $\mathrm{Hg}$ were reported respectively. After each run the electrode was held for $15 \mathrm{~s}$ at $+0.7 \mathrm{~V}$ to ensure the complete stripping of the deposited metals. In a further study [50] the authors reported a detection limit of $30 \mathrm{ng} / \mathrm{L}$ using a $600 \mathrm{~s}$ deposition time with a standard deviation of $1.8 \%$ for 20 repetitive measurements of a $25 \mu \mathrm{g} / \mathrm{L}$ solution of $\mathrm{Cu}$ in this case using a $60 \mathrm{~s}$ of deposition time. They showed the possibility of utilising the developed $\mathrm{Au}$ electrode for the analysis of $\mathrm{Cu}$ in sugar cane spirits and 
tap water samples. The results were shown to compare well with those obtained by atomic absorption spectroscopy.

\subsubsection{Cerium}

Westbroek et al [51] have described for the chronoamperometric determination of $\mathrm{Ce}(\mathrm{IV})$ in acidic aqueous solutions to study the kinetics and mechanism of polymerization reactions which utilise $\mathrm{Ce}(\mathrm{IV})$ as initiator. A thin layer cell was designed and constructed for flow injection analysis of Ce(IV) at a Au CD electrode in $1.0 \mathrm{M} \mathrm{H}_{2} \mathrm{SO}_{4}$. Using an applied potential of $+0.25 \mathrm{~V}$ a detection limit of $0.15 \mu \mathrm{M}$ was reported.

Daniel and Gutz have shown the possibility to develop flow through cell for the determination metal complexes such as ferricyanide [52]. In further studies they have developed novel micro-reactors, based on the $\mathrm{TiO}_{2}$-assisted photo-catalytic digestion of organic matter followed by the voltammetric determination of the liberated metal ion. In one such study [18] they showed the possibility of determining $\mathrm{Cu}^{2+}$ ions by cyclic voltammetry flowing liberation from its EDTA complex. For this they employed a $\mathrm{Au} \mathrm{CD}$ derived electrode modified with $\mathrm{TiO}_{2}$ by the voltammetric cycling ( -0.300 to $+1.100 \mathrm{~V}, 10$ scans) of a $\mathrm{AuCl}_{4}$ - in a suspension of $\mathrm{TiO}_{2}$. This resulted in the formation of a reportedly uniform brown deposit on the Au electrode surface. Electrodes modified by this procedure were reported to withstand at least one week of intense use. The electrochemical characteristics of the $\mathrm{TiO}_{2}$ modified $\mathrm{Au}$ electrode was evaluated using the reversible redox couple, $\left[\mathrm{Fe}(\mathrm{CN})_{6}\right]^{-3} /\left[\mathrm{Fe}(\mathrm{CN})_{6}\right]^{-4}$. An enhancement of $\mathrm{ca} .30 \%$ of the voltammetric currents was recorded at the modified electrode and was attributable to the increase in the effective surface area formed by the modification process. The $\mathrm{Cu}^{2+}$ EDTA complex was chosen as a model system to investigate the possibility of employing the photocatalytic micro-reactor for the removal of organic matter which is a well- 
known interference in the voltammetric determination of metal ions. In the absence of light no voltammetric signal for the electrochemical inactive $\mathrm{Cu}-\mathrm{EDTA}$ complex was recorded at the $\mathrm{Au}-\mathrm{TiO}_{2}$ modified electrode. Similarly, UV at irradiation at $365 \mathrm{~nm}$ of an unmodified $\mathrm{Au}$ electrode resulted in no detectable signal form the $\mathrm{Cu}$-EDTA complex. Whereas, irradiation at the $\mathrm{TiO}_{2}$-modified $\mathrm{Au}$ electrode was shown to result in the typical cyclic voltammetric response of $\mathrm{Cu}$, demonstrating the UV photo-catalytic destruction of the electrochemically inactive Cu-EDTA complex and the liberation of $\mathrm{Cu}^{2+}$ ions. The procedure was reported to be achieved in less than four minutes. In further studies the $\mathrm{Au}-\mathrm{TiO}^{2}$ modified electrode has been employed to determine ethylenediaminetetraacetic acid (EDTA) [53]. In this case the $\mathrm{Au}$ electrodes was modified by simply exposing the Au electrode to an acidic aqueous suspension of $\mathrm{P} 25 \mathrm{TiO}_{2}$. A layer of $\mathrm{TiO}_{2}$ less than $100 \mathrm{~nm}$ thick was reported to be formed on the Au surface, dominated by particles with diameters ranging from $20 \mathrm{~nm}$ (anatase) to $30 \mathrm{~nm}$ (rutile). A linear relationship between the photocurrent and the applied potential at the $\mathrm{TiO}_{2}$ modified Au electrode was reported. 


\begin{tabular}{|c|c|c|c|c|c|c|c|c|c|}
\hline $\begin{array}{l}\text { Analyt } \\
\text { e }\end{array}$ & $\begin{array}{l}\text { Electrode } \\
\text { Material }\end{array}$ & $\begin{array}{l}\text { Sample Pre- } \\
\text { treatment }\end{array}$ & $\begin{array}{l}\text { Supporting } \\
\text { Electrolyte }\end{array}$ & $\begin{array}{l}\text { Measurement } \\
\text { Technique }\end{array}$ & $\begin{array}{l}\text { Linear } \\
\text { Range }\end{array}$ & $\begin{array}{l}\text { Detection } \\
\text { Limit }\end{array}$ & Sample(s) & Comments & Ref. \\
\hline Hg & $\begin{array}{l}\text { Thin film } \\
\text { Au } \\
\text { electrodes } \\
\text { (Mitsui } \\
\text { Gold } \\
\text { Standard } \\
\text { CD), ca. } \\
5 \mathrm{~mm}^{2} \text {. }\end{array}$ & $\begin{array}{l}\text { Sonicated (15 } \\
\text { min) in } \\
\text { concentrated } \\
\mathrm{HC} 1 \text { and } \\
\mathrm{H}_{2} \mathrm{O}_{2}\end{array}$ & $\begin{array}{l}\text { Diluted } \mathrm{HCl} \\
\text { from the } \\
\text { sample pre- } \\
\text { treatment. }\end{array}$ & $\begin{array}{l}\text { stripping } \\
\text { chronopotentiometry }\end{array}$ & - & $\begin{array}{l}300 \mathrm{ng} / \mathrm{L} \\
(300 \mathrm{~s} \\
+300 \mathrm{mV})\end{array}$ & $\begin{array}{l}\text { Human } \\
\text { urine }\end{array}$ & $\begin{array}{l}\text { Samples } \\
\text { concentrations } \\
\text { verified by CV- } \\
\text { AAS and } \\
\text { analysis of } \\
\text { NIST SRM } \\
2670 .\end{array}$ & {$[54]$} \\
\hline Hg & $\begin{array}{l}\text { Thin film } \\
\text { Au } \\
\text { electrodes } \\
\text { (Mitsui } \\
\text { Gold } \\
\text { Standard } \\
\text { CD) }\end{array}$ & $\begin{array}{l}\text { Digested } \\
\text { using a } \\
\text { microwave } \\
\text { oven in } \\
\text { closed } \\
\text { vessels in } \\
\text { dilute } \mathrm{HNO}_{3} \\
\text { and } \mathrm{H}_{2} \mathrm{O}_{2}\end{array}$ & $\begin{array}{l}\text { Sample } \\
\text { digest. }\end{array}$ & $\begin{array}{l}\text { stripping } \\
\text { chronopotentiometry }\end{array}$ & - & $\begin{array}{l}5 \mathrm{ng} / \mathrm{g}(5 \\
\text { minutes, } \\
+300 \mathrm{mV})\end{array}$ & $\begin{array}{l}\text { fish and } \\
\text { shrimps }\end{array}$ & $\begin{array}{l}\text { Validated with } \\
\text { certified } \\
\text { reference } \\
\text { material. }\end{array}$ & [55] \\
\hline$\overline{\mathrm{Pb}, \mathrm{Cu}}$ & $\begin{array}{l}\text { Thin film } \\
\text { Au } \\
\text { electrodes } \\
\text { (Mitsui } \\
\text { Gold } \\
\text { Standard } \\
\text { CD), ca. } \\
5 \mathrm{~mm}^{2}\end{array}$ & $\begin{array}{l}\text { Sonicated (15 } \\
\text { min) in } 1: 1 \\
\text { concentrated } \\
\mathrm{HC} 1 \text { and } \\
\mathrm{H}_{2} \mathrm{O}_{2}\end{array}$ & $\begin{array}{l}\text { Diluted } \\
\text { extraction } \\
\text { solutions. }\end{array}$ & $\begin{array}{l}\text { Square-wave anodic } \\
\text { stripping voltammetry }\end{array}$ & - & $\begin{array}{l}\mathrm{Pb} \text { and } \mathrm{Cu} ; \\
67 \text { and } 23 \\
\mathrm{ng} / \mathrm{g} \\
\text { respectively } \\
(-250 \mathrm{mV}, \\
120 \mathrm{~s})\end{array}$ & $\begin{array}{l}\text { lubricating } \\
\text { oils }\end{array}$ & $\begin{array}{l}\text { Method } \\
\text { validated by } \\
\text { comparison } \\
\text { with GFAAS } \\
\text { and CSA }\end{array}$ & [56] \\
\hline $\mathbf{H g}$ & $\begin{array}{l}\text { Au, Kodak } \\
\text { Gold } \\
\text { Preservatio } \\
\text { n CD-R }\end{array}$ & $\begin{array}{l}\text { Digested in } \\
\mathrm{HNO}_{3} / \mathrm{HCl} / \\
\mathrm{H}_{2} \mathrm{SO}_{4} \text { by } \\
\text { heating at } \\
100{ }^{\circ} \mathrm{C} \text {. }\end{array}$ & $\begin{array}{l}0.05 \mathrm{M} \mathrm{HCl} \\
\text { solution } \\
\text { containing } \\
0.3 \mathrm{M} \\
\mathrm{Na}_{2} \mathrm{SO}_{4}\end{array}$ & $\begin{array}{l}\text { Flow injection stripping } \\
\text { chronopotentiometry }\end{array}$ & $\begin{array}{l}5-100 \\
\mathrm{ng} / \mathrm{mL} \\
(180 \mathrm{~s})\end{array}$ & $\begin{array}{l}0.1 \mathrm{ng} / \mathrm{mL} \\
(600 \mathrm{~s}, \\
+300 \mathrm{mV})\end{array}$ & $\begin{array}{l}\text { Cod fish } \\
\text { samples }\end{array}$ & $\begin{array}{l}\text { Recovery } 96.2 \\
\%\end{array}$ & [57] \\
\hline $\mathbf{P b}$ & Au CD-R & $\begin{array}{l}\text { Dilution in } \\
\text { electrolyte }\end{array}$ & $\begin{array}{l}50-300 \mathrm{mM} \\
\mathrm{HCl}\end{array}$ & SWASV & - & $\begin{array}{l}80 \mathrm{ng} / \mathrm{L} \\
(300 \mathrm{~s})\end{array}$ & Rainwater & $\begin{array}{l}\text { Validated with } \\
\text { certified } \\
\text { reference } \\
\text { material }\end{array}$ & [45] \\
\hline $\mathbf{P b}$ & $\begin{array}{l}\mathrm{Ag}, \\
\text { Verbatim }\end{array}$ & $\begin{array}{l}\text { Dilution with } \\
0.2 \mathrm{M} \mathrm{HCl}\end{array}$ & $0.1 \mathrm{M} \mathrm{HCl}$ & DPASV & $\begin{array}{l}20- \\
350\end{array}$ & $\begin{array}{l}6 \mathrm{ng} / \mathrm{mL} \\
(100 \mathrm{~s})\end{array}$ & $\begin{array}{l}\text { Roof runoff } \\
\text { water }\end{array}$ & - & {$[7]$} \\
\hline
\end{tabular}




\begin{tabular}{|c|c|c|c|c|c|c|c|c|c|}
\hline & CD-R & & & & $\mathrm{ng} / \mathrm{mL}$ & & & & \\
\hline $\begin{array}{l}\mathrm{Hg}, \\
\mathrm{CH}_{3} \mathrm{Hg}^{+}\end{array}$ & $\begin{array}{l}\text { Au Mitsui } \\
\text { Gold } \\
\text { Standard } \\
\text { CD-R }\end{array}$ & & & $\begin{array}{l}\text { Stripping } \\
\text { chronoamperometry }\end{array}$ & & $\begin{array}{l}8 \mathrm{ng} / \mathrm{L}, \\
180 \mathrm{~s}\end{array}$ & $\begin{array}{l}\text { Synthetic } \\
\text { ocean } \\
\text { water }\end{array}$ & \begin{tabular}{|l|} 
NIST river \\
water (recovery \\
$93-105 \%)$
\end{tabular} & [49] \\
\hline $\mathrm{Hg}, \mathrm{Cu}$ & $\mathrm{Au} C \mathrm{CD}$ & & $0.1 \mathrm{M} \mathrm{HCl}$ & $\begin{array}{l}\text { Potentiometric } \\
\text { stripping }\end{array}$ & $\begin{array}{l}5-60 \\
\mathrm{ng} / \mathrm{mL} \\
\mathrm{Cu}, 10 \\
-120 \\
\mathrm{ng} / \mathrm{mL} \\
\mathrm{Hg}\end{array}$ & & & & [9] \\
\hline $\begin{array}{l}\mathrm{Pb}, \mathrm{Cu}, \\
\mathrm{Hg}, \mathrm{Cd}\end{array}$ & $\begin{array}{l}\text { Au CD with } \\
\text { in situ } \\
\text { formed } \mathrm{Bi} \\
\text { film }\end{array}$ & & $\begin{array}{l}0.5 \mathrm{M} \mathrm{KCl} \\
\text { and } 6.0 \mathrm{mM} \\
\mathrm{HCl} \text { for } \mathrm{Cu} \\
\text { and } \mathrm{Hg} . \mathrm{Cd} \\
\text { and } \mathrm{Pb} 0.1 \\
\mathrm{M} \text { acetate } \\
\text { buffer }(\mathrm{pH}\end{array}$ & $\begin{array}{l}\text { Potentiometric } \\
\text { stripping and SWASV. }\end{array}$ & $\begin{array}{l}10- \\
100 \\
\mu \mathrm{g} / \mathrm{L}\end{array}$ & $\begin{array}{l}\mathrm{Cd}^{2+} 0.38 \\
\mu \mathrm{g} / \mathrm{L} ; \mathrm{Pb}^{2+}, \\
0.74 \mu \mathrm{\mu g} / \mathrm{L} \\
(\mathrm{S} / \mathrm{N}=3) .\end{array}$ & -- & \begin{tabular}{|l} 
Microfluidic \\
cell (internal \\
volume 0.6 to \\
$2.4 \mu \mathrm{L}$ ) with Ag \\
epoxy pseudo- \\
reference \\
electrode. $\mathrm{Au}$ \\
\end{tabular} & 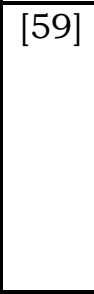 \\
\hline
\end{tabular}




\begin{tabular}{|c|c|c|c|c|c|c|c|c|c|}
\hline & & & $\begin{array}{l}4.7) \\
\text { containing } \\
2.0 \mathrm{mg} / \mathrm{L} \text { of } \\
\mathrm{Bi} .\end{array}$ & & & & & $\begin{array}{l}\text { CD working } \\
\text { electrode. } \\
\text { Graphite } \\
\text { working } \\
\text { electrode also } \\
\text { explored. }\end{array}$ & \\
\hline $\mathbf{C u}$ & $\mathrm{Au} C D$ & & $0.1 \mathrm{M} \mathrm{HCl}$ & $\begin{array}{l}\text { Potentiometric } \\
\text { stripping analysis }\end{array}$ & & $\begin{array}{l}30 \mathrm{ng} / \mathrm{L} \\
(600 \mathrm{~s} \\
\text { accumulati } \\
\text { on time) }\end{array}$ & $\begin{array}{l}\text { Sugar cane } \\
\text { sprit and } \\
\text { tap water }\end{array}$ & - & {$[50]$} \\
\hline $\mathbf{C u}$ & $\begin{array}{l}\text { Au CD with } \\
\text { amine- } \\
\text { functionalis } \\
\text { ed silica } \\
\text { film. }\end{array}$ & & $\begin{array}{l}\text { Accumulati } \\
\text { on in 50:50 } \\
\text { ethanol:wat } \\
\text { er solution }\end{array}$ & $\begin{array}{l}\text { Open circuit } \\
\text { accumulation of } \mathrm{Cu}^{2+} \\
\text { at a } 10 \% \text { amine } \\
\text { functionalised silica } \\
\text { surface, followed by } \\
\text { measurement by } \\
\text { DPASV (reduction } \\
\text { at }-1.2 \mathrm{~V}) \text {. }\end{array}$ & $\begin{array}{l}0.1- \\
10 \mu \mathrm{M}\end{array}$ & & $\overline{--}$ & $\begin{array}{l}\text { Reactivation } \\
\text { at }-1.3 \mathrm{~V} \text { for } 3 \\
\text { minutes. }\end{array}$ & {$[60]$} \\
\hline $\mathbf{C u}$ & $\begin{array}{l}\mathrm{Au} \mathrm{CD} \\
\mathrm{TiO}_{2-} \\
\text { modified }\end{array}$ & $\begin{array}{l}\text { Thin layer } \\
\text { micro- } \\
\text { reactor. } 100 \\
\mathrm{~mW} \text { UV-LED } \\
\text { ( } 365 \mathrm{~nm}) \\
\text { focused on } \\
\text { the modified } \\
\text { electrode. }\end{array}$ & $\begin{array}{l}\text { Acetate } \\
\text { buffer } \\
\text { solution }(\mathrm{pH} \\
4.7)\end{array}$ & $\begin{array}{l}\text { Cyclic voltammetry, } 50 \\
\mathrm{mV} / \mathrm{s} .\end{array}$ & $\begin{array}{l}1.0 \times 10^{-} \\
6 \mathrm{M}- \\
5.0 \times 10^{-} \\
{ }^{3} \mathrm{M}\end{array}$ & $\begin{array}{l}5 \times 10^{-15} \mathrm{M} \\
\mathrm{Cu}\end{array}$ & $\begin{array}{l}\text { Model Cu- } \\
\text { EDTA } \\
\text { complex }\end{array}$ & $\begin{array}{l}\text { In situ } \\
\text { photocatalytic } \\
\text { digestion Cu- } \\
\text { EDTA complex } \\
\text { as model } \\
\text { complex. }\end{array}$ & {$[18]$} \\
\hline $\mathrm{Se}(\mathrm{IV})$ & $\mathrm{Au} \mathrm{CD}$ & - & $\begin{array}{l}0.1 \mathrm{M} \\
\mathrm{HClO}_{4}\end{array}$ & DPASV & $\begin{array}{l}0.5- \\
291 \\
\mathrm{ng} / \mathrm{mL}\end{array}$ & - & $\begin{array}{l}\text { Standard } \\
\text { reference } \\
\text { solutions }\end{array}$ & & {$[46]$} \\
\hline Se(IV) & $\mathrm{Au} \mathrm{CD}$ & $\begin{array}{l}\text { Microwave } \\
\text { aided } \\
\text { digestion in } \\
\mathrm{HNO}_{3} \text { and } \\
\mathrm{H}_{2} \mathrm{SO}_{4} .\end{array}$ & $\begin{array}{l}0.1 \mathrm{M} \\
\mathrm{HClO}_{4}\end{array}$ & $\begin{array}{l}\text { Flow injection } \\
\text { differential pulse } \\
\text { amperometry, }-0.4 \mathrm{~V}\end{array}$ & $\begin{array}{l}20 \text { to } \\
400 \\
\mu g / L\end{array}$ & $\begin{array}{l}6 \mu g / L \\
200 \mathrm{~s}\end{array}$ & $\begin{array}{l}\text { Fish } \\
\text { tissue. }\end{array}$ & $\begin{array}{l}\text { Flow injection } \\
\text { analysis, } 0.71 \\
\mathrm{~mL} / \mathrm{min}\end{array}$ & {$[61]$} \\
\hline $\mathbf{C e}(I V)$ & $\mathrm{Au} \mathrm{CD}$ & & $\begin{array}{l}1.0 \mathrm{M} \\
\mathrm{H}_{2} \mathrm{SO}_{4}\end{array}$ & Amperometry $+0.25 \mathrm{~V}$ & & $0.15 \mu \mathrm{M}$ & & $\begin{array}{l}\text { Flow injection } \\
\text { analysis, } 2.36 \\
\mathrm{~mL} / \mathrm{min}\end{array}$ & {$[51]$} \\
\hline
\end{tabular}




\begin{tabular}{|c|c|c|c|c|c|c|c|c|}
\hline $\mathbf{Z n}$ & $\begin{array}{l}\text { Au CD with } \\
\text { Hg film }\end{array}$ & $\begin{array}{l}\text { Sample } \\
\text { digested in } \\
1: 1 \\
\text { concentrated } \\
\mathrm{HCl}: \mathrm{H}_{2} \mathrm{O}_{2} \\
\text { with the aid } \\
\text { of sonication. }\end{array}$ & $\begin{array}{l}0.2 \mathrm{M} \\
\text { acetic acid } \\
+0.2 \mathrm{M} \\
\text { sodium } \\
\text { acetate }\end{array}$ & $\begin{array}{l}\text { Potentiometric } \\
\text { stripping. }-1.45 \mathrm{~V} \text { (vs. } \\
\mathrm{Ag} / \mathrm{AgCl} \text { ) }\end{array}$ & $\begin{array}{l}1.35 \mu \mathrm{g} / \mathrm{L} \\
\text { for } 45 \mathrm{~s} \\
\text { and } 0.030 \\
\mu \mathrm{g} / \mathrm{L} \text { for } \\
600 \mathrm{~s} \text { pre- } \\
\text { concentrati } \\
\text { on }\end{array}$ & $\begin{array}{l}\text { Coconut } \\
\text { water. }\end{array}$ & $\begin{array}{l}\text { Cu also } \\
\text { determined, } \\
\text { but below limit } \\
\text { of detection. } \\
\text { Good } \\
\text { agreement } \\
\text { with GFASS. }\end{array}$ & {$[$ [62] } \\
\hline $\mathbf{C u}$ & $\mathrm{Au} \mathrm{CD}$ & $\begin{array}{l}\text { Focused } \\
\text { microwave } \\
\text { aided } \\
\text { digestion in } \\
\mathrm{HNO}_{3} / \\
\mathrm{H}_{2} \mathrm{SO}_{4} / \mathrm{H}_{2} \mathrm{O}_{2} .\end{array}$ & $\begin{array}{l}20 \mathrm{mM} \\
\mathrm{NaCl} .\end{array}$ & $\begin{array}{l}\text { Derivative } \\
\text { potentiometric } \\
\text { stripping. } 0.8 \mathrm{~V}\end{array}$ & $\begin{array}{l}92 \mathrm{ng} / \mathrm{g} \text { oil } \\
\text { for } 120 \mathrm{~s} \text {. }\end{array}$ & $\begin{array}{l}\text { Lubricatin } \\
\text { g oils. }\end{array}$ & $\begin{array}{l}\mathrm{Pb} \text { also } \\
\text { determined at } \\
\text { glassy carbon } \\
\text { electrode. } \\
\text { Good } \\
\text { agreement } \\
\text { with GFASS. }\end{array}$ & [63] \\
\hline $\begin{array}{l}\mathbf{C u}, \mathbf{P b}, \\
\mathbf{H g}, \mathbf{Z n}\end{array}$ & $\begin{array}{l}\text { Au CD with } \\
\text { Hg film for } \\
\text { potentiomet } \\
\text { ric } \\
\text { stripping }\end{array}$ & $\begin{array}{l}\text { Focused } \\
\text { microwave } \\
\text { aided } \\
\text { digestion in } \\
\mathrm{HNO}_{3} / \\
\mathrm{H}_{2} \mathrm{SO}_{4} / \mathrm{H}_{2} \mathrm{O}_{2} .\end{array}$ & $\begin{array}{l}\text { Square } \\
\text { wave } \\
\text { stripping } \\
\text { voltammetr } \\
\text { y } 20 \mathrm{mM} \\
\mathrm{NaCl} . \\
\text { Potentiomet } \\
\text { ric stripping } \\
100 \mathrm{mM} \mathrm{Na} \\
\text { acetate. }\end{array}$ & $\begin{array}{l}\text { Square wave stripping } \\
\text { voltammetry (Cu, } \mathrm{Pb}, \\
\mathrm{Hg}) \text {, stripping } \\
\text { chronopotentiometry } \\
(\mathrm{Cu}, \mathrm{Pb}, \mathrm{Zn}) \text { and } \\
\text { potentiometric } \\
\text { stripping }(\mathrm{Cu}, \mathrm{Pb}, \mathrm{Zn}) \text {. }\end{array}$ & $\begin{array}{l}\text { Square } \\
\text { wave } \\
\text { stripping } \\
\text { voltammetr } \\
\text { y } \mathrm{Pb} 0.04 \\
\mu \mathrm{g} / \mathrm{L}, \mathrm{Cu} \\
1.4 \mu \mathrm{g} / \mathrm{L}, \\
\mathrm{Hg} 1.3 \\
\mu \mathrm{g} / \mathrm{L} . \\
\text { Stripping } \\
\text { chronopote } \\
\text { ntiometry } \\
\mathrm{Cu} 0.65 \\
\mu \mathrm{g} / \mathrm{L}, \mathrm{Hg} \\
0.69 \mu \mathrm{g} / \mathrm{L} \\
\end{array}$ & $\begin{array}{l}\text { Crude oil } \\
\text { and } \\
\text { petroleum } \\
\text { based } \\
\text { fuels. }\end{array}$ & $\begin{array}{l}\text { Good } \\
\text { agreement } \\
\text { with GFASS. }\end{array}$ & [64] \\
\hline
\end{tabular}

Table 1. Application of CD and DVD electrodes for the determination of metal ions.

Cold vapour atomic absorption spectrometry (CV-AAS), chronopotentiometric-stripping analysis (CSA), Graphite furnace atomic absorption spectrometry (GFASS), National Institute of Standards and Technology standard reference material (NIST SRM). 
Table 2 summaries the wide range of different applications other than metal ion analysis that have been reported utilising CD and DVD based electrodes.

\section{Biomedical and Environmental Applications}

\subsection{Chagas' Disease}

Chagas' disease is a parasitic infection caused by the hemoflagellate Trypanosoma cruzi (T. cruzi) transmission of this disease is through the bite of contaminated hematophagous insects or through blood transfusion and blood components. Foguel et al [65,66] have developed an amperometric immunosensor for the determination of Chagas' disease based on a Au CD-R modified with 4(methylmercapto)benzaldehyde (SBZA) for the immobilization of the Tc85 protein of T. cruzi.

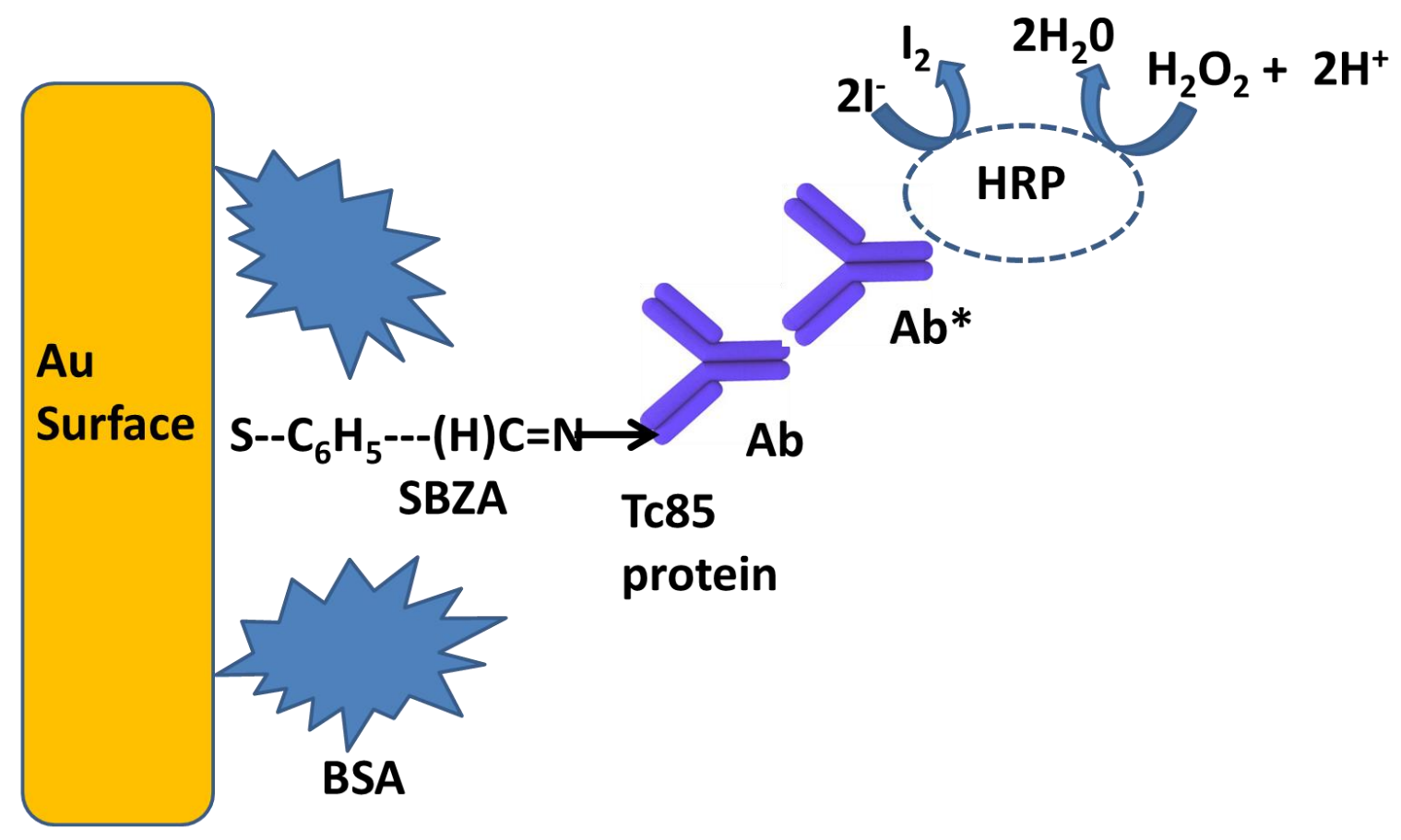

Figure 3. Chagas' immunosensor construction scheme, after Foguel et al [65].

The Au electrodes were cleaned by voltammetric cycling in $0.5 \mathrm{M}$ sulphuric acid over the potential range $0.0 \mathrm{~V}$ and $+1.5 \mathrm{~V}$ at $100 \mathrm{mV} / \mathrm{s}$. The amperometric 
immunosensor was then fabricated by modifying the surface of the Au CD electrode with a self-assembled monolayer of SBZA. The antigen Tc85 protein of T. cruzi was immobilised on the SBZA modified surface. After antigen immobilisation the immunoassay was performed by first blocking of the sensor surface with a saline phosphate buffer-Tween solution containing $0.5 \%$ bovine serum albumin (Ab) (Figure 3). A $50 \mu \mathrm{L}$ sample of serum diluted in blocking solution was then applied and following a wash step, anti-human IgG antibody conjugated to peroxidase (Ab*) was applied and incubation for 15 minutes. The resulting immunoenzymatic reaction was monitored by chronoamperometry using hydrogen peroxide as the substrate meditated by potassium iodide in $\mathrm{pH} 7.00 .1 \mathrm{M}$ phosphate buffer solution.

\subsection{Thrombin}

The protein thrombin regulates many processes in inflammation and tissue repair at the blood vessel wall. Frense et al [67] have recently reported on the application of an impedance based thrombin biosensor utilising immobilized streptavidin and a biotinylated aptamer as sensitive layer on the Au CD (Sony). The Au surface of the Au $C D$ was exposed by removing the lacquer film by submerging the $\mathrm{CD}$ in $50 \%$ nitric acid for 5 minutes. The exposed Au surface was rinsed with ethanol and then treated under UV to make the surface more hydrophilic. The Au surface was then sprayed with positive photoresist lacquer for photolithographic wet-etching of the electrode patterns (etched with $4 \mathrm{~g} \mathrm{KI}$ and $1 \mathrm{~g} \mathrm{I}_{2}$ in $40 \mathrm{~mL}$ water for 5 minutes). Two different electrode patterns were fabricated; the first pattern had a fixed measurement chamber glued to the electrode surface so sample volumes of $50 \mu \mathrm{L}$ to $400 \mu \mathrm{L}$ can be used. The second was used as part of a flow-through channel chamber; based on an interdigitated electrode (IDE) design. Samples of $15 \mu \mathrm{L}$ to 90 $\mu \mathrm{L}$ can be applied. The surface of the Au electrode was modified with cysteamine (20 $\mathrm{mM}$ for $2 \mathrm{~h}$ ) and glutaraldehyde (300 $\mathrm{mM}$ for $2 \mathrm{~h}$ ) for the protein binding. 
Streptavidin, $1 \mu \mathrm{g} / \mathrm{mL}$ diluted in phosphate saline buffer solution, was then immobilized via the aldehyde groups. After blocking non-specific binding sites with bovine serum albumin, the biotinylated aptamer thrombin-binding aptamer (TBA) was then immobilised. Electrochemical impedance spectroscopy (EIS) was performed frequency range from $100 \mathrm{mHz}$ to $200 \mathrm{kHz}$.

\subsection{DNA}

Ahangar and Mehrgardi [68] have fabricated a nano-porous Au electrode (NPGE) from $\mathrm{Au} C D-R s$ for the electrochemical detection of single base mismatches using a ferrocene-modified DNA probe. The Au electrode was prepared from small pieces of $\mathrm{CD}-\mathrm{R}$ placed in nitric acid to remove the protective layer. This was then secured to the bottom of a Teflon cell with an O-ring. The NPGE was constructed in two steps. Firstly, the Au surface of the CD-R was anodized in a phosphate buffer solution $(\mathrm{pH}$ 7.4) for 3 minutes, by applying a potential of $+3.6 \mathrm{~V}$ vs. $\mathrm{Ag} / \mathrm{AgCl}$. Following this the anodized $\mathrm{Au}$ surface was reduced with $1.0 \mathrm{M}$ of ascorbic acid for 5 minutes reducing the gold oxide to metallic gold. The unprotected modified DNA was drop coated onto the $\mathrm{Au} \mathrm{CD}$ electrode and with $\mathrm{MgCl}_{2}$ and $\mathrm{NaH}_{2} \mathrm{PO}_{4}$. An aqueous solution of 6-mercaptohexanol was then added to the modified electrode surface and the electrode washed. A $4 \mu \mathrm{M}$ aliquot of the target DNA was then introduced to the electrode surface with $5 \mu \mathrm{L}$ of $2 \mathrm{M} \mathrm{MgCl}_{2}$. The electrode and sample solution were then left to incubate for 7 hours in the dark and examined electrochemically. Differential pulse voltammetry was utilised to quantify the ferrocene carboxylic acid labelled DNA present at the Au electrode. An oxidation peak with a peak potential of $+0.2 \mathrm{~V}$ ( $v$ s. $\mathrm{Ag} / \mathrm{AgCl}$ ) was reported and levels as low as $25 \mathrm{pM}$ could be detected.

\subsection{Glucose}

Glucose is a very important analyte; be it for monitoring blood levels by diabetics or in the food and beverage industries. A large number of enzyme based sensors have been developed and commercialised to meet these demands. Recently, Chen et al 
[69] have reported the direct non-enzymatic determination of blood glucose levels at a Ag electrode manufactured from a CD-R. Initial voltammetric investigations on different glucose levels were recorded over the potential range from $-0.7 \mathrm{~V}$ to $0 \mathrm{~V}$. A concentration dependent voltammetric wave was record, with a peak potential (Ep) of $-0.5 \mathrm{~V}$. Using amperometry in a $\mathrm{pH} 6.5$ phosphate buffered solution with an applied potential of $-0.50 \mathrm{~V}$ a linear range of $0.5-13 \mathrm{mM}(\mathrm{r}=0.996)$ was obtained. The authors postulate that this electrochemical response is due to an electroabsorbed glucose intermediate species on the surface of the Ag electrode this species can be then oxidised resulting the voltammetric wave reported. A tentative mechanism for this oxidation has been given and it is thought to occur at the carbon $\mathrm{C} 1$ atom of glucose [70]. The possibility of determining glucose levels in human blood sample was investigated. A $15 \mu \mathrm{L}$ aliquot of human blood obtained from healthy fasting humans subjects was mixed with an equal volume of $0.1 \mathrm{M}$ phosphate buffer. Amperometric measures showed glucose recoveries of $95.7 \%$ to $101.3 \%$ and the accuracy of the readings evaluated by comparison to measurements made by diabetic patients and by hospital staff using a glucose oxidase based biosensor (YSI Model 2300 Glucose Analyzer, Yellow Springs Instruments, Yellow Springs, OH). Good agreement was reported between the two devices and it was concluded that the sensor showed the possibility of a nonenzymatic method for the determination of human blood glucose levels.

\subsection{Ascorbic Acid}

Muñoz et al [71] developed an amperometric flow injection system of the determination of ascorbic acid. A Au CD modified by the electrodeposition of Pt by electrochemical deposition of $\mathrm{Pt}\left(\mathrm{K}_{2} \mathrm{PtCl}_{4}\right.$ solution $2 \mathrm{mM}, \mathrm{pH} 4.8$ at $-1.00 \mathrm{~V}$ for 15 min). Spectroscopic investigation showed a uniform platinum deposit, with a very rough surface. Cyclic voltammetric investigations of unmodified electrodes in a $\mathrm{pH}$ 
4 buffer showed no response for ascorbic acid over the potential range 0.0 to +0.8 V. However, once electroplated with Pt a broad oxidation peak was recorded (Ep $+0.45 \mathrm{~V})$. The possibility of applying this response for the determination of ascorbic acid was explored by determining its concentration in commercial pharmaceutical tablets. The results obtained were identical than the ones obtained by the classical iodometric method. Calibration plots were linear over the range of $1-10 \mu \mathrm{M}$ with a relative standard deviation of $1 \%$ with a corresponding detection limit of $0.78 \mu \mathrm{M}$ reported. The modified electrodes were stable for at least one week under reportedly intense usage. The possibility of utilising a single channel flow cell was also investigated, using an aquarium air pump to propel the moving phase. Using amperometric detection with an applied potential of $+0.40 \mathrm{~V}$ ( $v s$. $\mathrm{Ag} / \mathrm{AgCl}$ ), the effect of flow rate was investigated over the range 0.5 to $9.0 \mathrm{~mL} / \mathrm{min}$ The signal was reported to increase with flow rate from 0.5 to $2.5 \mathrm{~mL} / \mathrm{min}$ and then remained constant at flow rates above this, with a flow rate of $2.5 \mathrm{~mL} / \mathrm{min}$ being reported as being optimal. The incomplete dissolution of other constituents of the tablets were reported not to affect the amperometric analysis. Eight different ascorbic acid containing pharmaceutical formulations were investigated and coefficients of variation ranging between 0.5 and $2.3 \%$ were reported.

Latino et al [72] have utilised a $\mathrm{Au} C D$ for the determination of ascorbic acid. The $\mathrm{CD}$ was chemically etched in a $50 \%$ aqueous solution of nitric acid at $80{ }^{\circ} \mathrm{C}$ to remove the upper protective layer to expose the Au metal sublayer. The layout of the electrodes was designed using computer aided design (CAD). A LPKF Protomat S103 rapid prototyping system was used to outline the design of the electrodes on the prepared $\mathrm{Au} C D$ substrate. The designed electrodes in the Gerber format were then processed by milling machine. Two different sensors were fabricated; the first as a "serpentine" type temperature sensor which was shown to give a linear response with temperature from room temperature $\left(c a .25^{\circ} \mathrm{C}\right)$ up to $65^{\circ} \mathrm{C}$. The 
second type was developed for the voltammetric determination of ascorbic acid. Cyclic voltammetric investigations were undertaken in $0.1 \mathrm{M} \mathrm{KCl}$. A characteristic oxidation peak was reported at $+0.8 \mathrm{~V}$. Using a sample volume of $150 \mu \mathrm{L}$ the flow system allowed for determinations of $1 \mu \mathrm{M}$ of the analyte to be made with the possibility of making 90 determinations per hour.

\subsection{Dopamine}

Dopamine has been determined at electrodes fabricated from $\mathrm{Au} C D-\mathrm{R}$ disks (Mitsui MAM-M Standard Gold CD-R) modified using the technique of xurography [73]. The layout of the electrodes was drawn using the CorelDraw 11.0 software package and the electrodes fabricated using a cutting plotter. Using this approach it was reported to be possible to fabricate circular structures as small as $447 \pm 12$ $\mu \mathrm{m}(\mathrm{n}=3)$ in diameter and square shaped structures (microchannels) down to $107 \pm 13 \mu \mathrm{m}(\mathrm{n}=3)$ in width.

The electrochemical performance of these devices was investigated by square wave voltammetry using a $40 \mu \mathrm{M}$ solution of ferricyanide with electrodes with increasing nominal diameters from 0.50 to $3.0 \mathrm{~mm}$. Well-defined peaks with an Ep values of $+0.218 \mathrm{~V}$ was reported. The peak current showed a linear relationship with electrode area.

Dopamine is reported to promote Au surface passivation, factor that was investigated to illustrate the important advantage of using disposable electrodes in such applications. However, no linear relationship between peak current and dopamine concentration was observed when performing the same experiments using a single electrode. A gradual decrease in the current was reported while increasing the concentration of dopamine. This behaviour is commonly observed due to the formation of a polymeric film on the electrode surface. However, by using a new electrode for each determination this effect was overcome and a linear 
response for dopamine over the concentration range 20 to $100 \mu \mathrm{M}$ by square wave voltammetry.

\subsection{Cysteine}

At Au electrodes similar issues are seen with other strongly adsorbed species such as cysteine to that reported for dopamine. However, the disposable nature of the Au CD electrodes has been shown to avoid these problems. Lowinsohn et al [74] have used toner masks laser printed and heat transferred to Au CD surfaces to define the area of the working electrode area. The authors reported that the size of the disc electrodes could be easily controlled and electrodes with radii varying from $0.5 \mathrm{~mm}$ to $3.0 \mathrm{~mm}$ could be readily fabricated. The authors showed that repeated application of solutions containing cysteine to the same Au electrode resulted in a degradation of response due to adsorption of oxidation products on the electrode surface. This problem was shown to be readily overcome by using a new working electrode for each measurement. Such a situation would be an expensive solution when using conventional Au electrodes. However, Au electrodes fabricated from $\mathrm{CD}$ as this case could be treated as disposable and hence can be discarded after each measurement. Using such an approach no degradation of response was reported for the square wave voltammetric determination of cysteine over the concentration range $20 \mu \mathrm{g} / \mathrm{L}$ to $100 \mu \mathrm{g} / \mathrm{L}$.

\subsection{Hydrogen Peroxide}

Hydrogen peroxide is an important analyte to measure in a number of different applications, as diverse as electrochemical biosensors, forensic analysis, and agriculture. Recently, several studies have utilised electrochemically roughened Ag $\mathrm{CD}$ based electrodes for the electro-catalytic determination of hydrogen peroxide [4,5]. By multiple cyclic voltammetric scanning of the Ag electrode dendritic 
nanostructures can be generated on the electrode surface which have been shown to improve the electrochemical performance of the electrodes for the detection of hydrogen peroxide. Lain et al [4] have reported the optimum conditions for these roughening electrochemical oxidation-reduction voltammetric cycles to be five cycles of $-0.35 \mathrm{~V}$ to $+0.35 \mathrm{~V}$ in a $0.2 \mathrm{M} \mathrm{KCl}$ solution at a scan rate of $5 \mathrm{mV} / \mathrm{s}$. Utilising amperometry in stirred solution a linear range of $10.0 \mu \mathrm{M}$ to $22.5 \mathrm{mM}(\mathrm{R}=$ $0.999 ; \mathrm{n}=19)$ with an associated detection limit of $6 \mu \mathrm{M},(\mathrm{s} / \mathrm{n}=3$ ) was reported. No interferences in the determination of hydrogen peroxide in the presence of 10 fold ascorbic or uric acid were reported. However, the presence of a fivefold concentration of $\mathrm{Fe}^{3+}$ resulted in a $10 \%$ increase in signal current.

More recently, Shafei and Honeychurch [75] have utilised an unmodified Ag electrode manufactured from a DVD-R for the determination of hydrogen peroxide in water. A Verbatim DVD-R was simply mechanically delaminated and the exposed Ag layer used as the working electrode without further modification. A 5 $\mathrm{mm}$ working area was defined with dielectric tape and the resulting Ag working electrode was used as part of a three electrode system. Using a cyclic voltammetric waveform, a limit of detection of $78.35 \mu \mathrm{M}$ (based on three times the standard deviation of the noise) was recorded with a linear range from $0.087 \mathrm{mM}$ to $3.41 \mathrm{mM}$ $\left(\mathrm{R}^{2}=0.996\right)$ hydrogen peroxide. Figure 4 shows the typical cyclic voltammograms and resulting standard addition plot obtained for a potable water sample. The results indicate that a method based on multiple standard additions was both accurate and precise, obtaining a coefficient of variation of $4.69 \%$ for a water sample fortified with $40.8 \mathrm{mg} / \mathrm{L}(1.2 \mathrm{mM})$; levels commonly reported in aquaculture and swimming pools applications. 

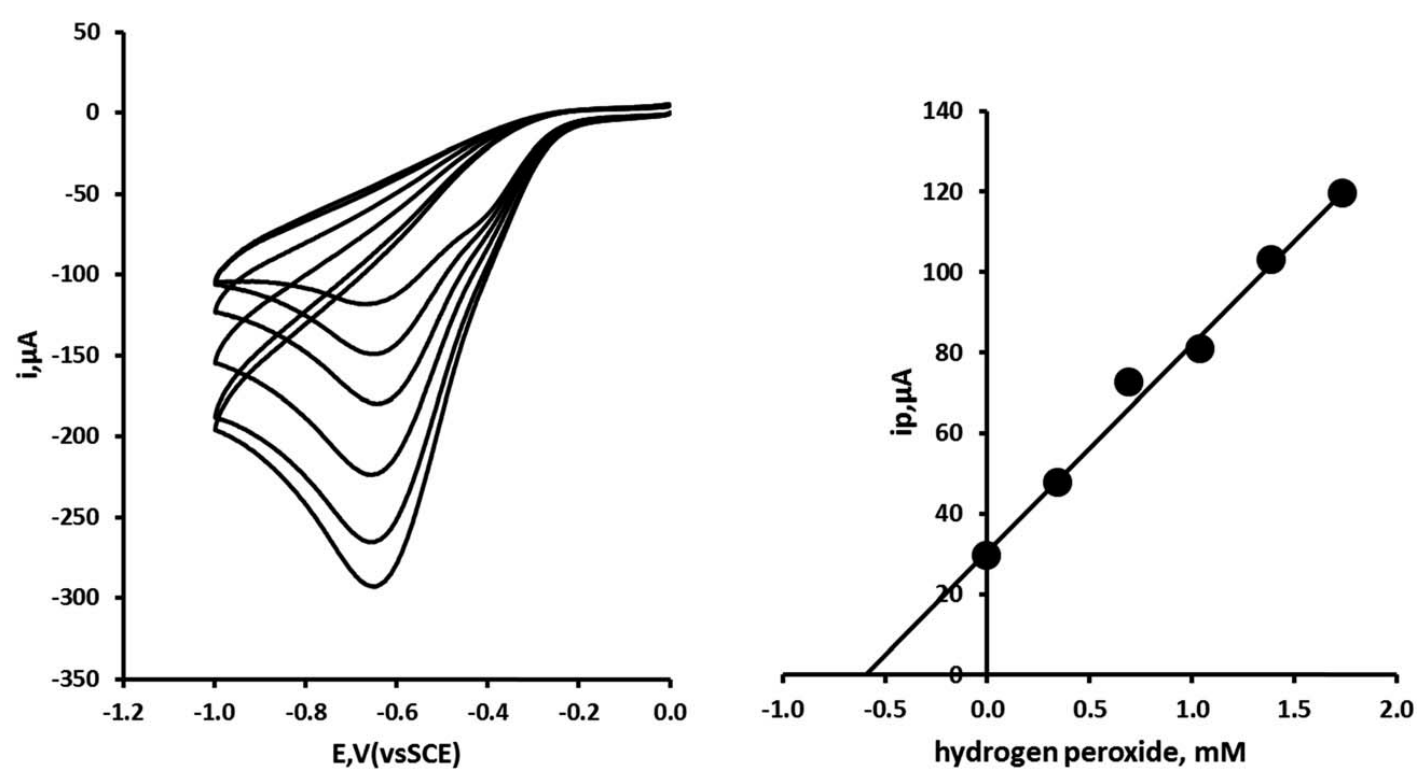

Figure 4. Multiple standard additions of hydrogen peroxide made to water sample fortified with $1.2 \mathrm{mM}(40.8 \mathrm{mg} / \mathrm{L})$ hydrogen peroxide. Each addition the equivalent of $348 \mu \mathrm{M}(11.8 \mathrm{mg} / \mathrm{L})$ hydrogen peroxide. Reproduced from [75] with permission from the Royal Society of Chemistry.

Paixão and Bertotti [76] have reported the development of a disposable voltammetric electronic tongue based on an electrode array for the determination of hydrogen peroxide in milk available in the Brazilian market. The addition of hydrogen peroxide to milk is prohibited leading to a demand for an efficient method for monitoring its possible presence in milk samples. The voltammetric tongue array was constructed from $\mathrm{Au} C D-\mathrm{R}$ and $\mathrm{Cu}$ sheet as substrates with sensing elements of $\mathrm{Au}, \mathrm{Cu}$ and a $\mathrm{Au}$ electrodes modified with a layer of Prussian Blue (PB). The individual $\mathrm{Au}$ and $\mathrm{Cu}$ working electrodes were formed by first printing toner masks to protect the metallic surface. The layout of the electrodes was defined using graphic software (Open Office.org 2.4, Sun Microsystems Inc.). The gold layer of the $\mathrm{CD}-\mathrm{R}$ was first exposed with $\mathrm{HNO}_{3}$ solution before the heat-transfer of the toner mask which was laser-printed onto waxed paper. The exposed metal layers (not covered with toner) were removed with iodine/iodide ( $25 \mathrm{~g} / \mathrm{L}$ iodine and $100 \mathrm{~g} / \mathrm{L}$ sodium iodide) and ferrous perchlorate $(42 \%, \mathrm{w} / \mathrm{v})$ solutions. The toner mask was then removed with acetonitrile. A subset of electrodes were modified with a film of PB formed by potential cycling between -0.5 and $+0.7 \mathrm{~V}$ (15 cycles) at 
$100 \mathrm{mV} / \mathrm{s}$ in a solution of $1 \mathrm{mM} \mathrm{FeCl}_{3}, 1 \mathrm{mM} \mathrm{K}_{3} \mathrm{Fe}(\mathrm{CN})_{6}, 0.2 \mathrm{M} \mathrm{HCl}$ and $0.35 \mathrm{M}$ KCl. The possibility of combining two individual working electrodes together as sensing units to identify basic taste substances (quinine for bitterness, sucrose for sweetness, $\mathrm{HCl}$ for sourness, and $\mathrm{KCl}$ for saltiness) was investigated. Cyclic voltammetric investigations of the four taste standards showed that the $\mathrm{Au}$ and $\mathrm{PB}$ modified electrodes gave good responses for $\mathrm{HCl}$ and $\mathrm{KCl}$. Copper electrodes also showed good responses for both $\mathrm{HCl}$ and $\mathrm{KCl}$ but were also able to discriminate sucrose from quinine solutions. Further cyclic voltammetric investigations were recorded using this integrated sensor in three samples of untreated homogenized/pasteurized milk in the absence and presence of hydrogen peroxide at $0.015,0.30$ and $3.0 \%(\mathrm{v} / \mathrm{v})$. Using principle component analysis the ability of the integrated sensor system to discriminate samples containing hydrogen peroxide was shown to be possible.

\subsection{Iodine}

Lindino et al [77] have determined the concentration of iodate in table salt amperometically using an applied potential of $+0.1 \mathrm{~V}$ vs. $\mathrm{Ag} / \mathrm{AgCl}$ at $\mathrm{Au} \mathrm{CD}-\mathrm{R}$ based electrodes. The response time after the addition of each aliquot of the sample or standard was reported to be four seconds. The relative deviation between the measurement of iodate in a synthetic sample of salt, was of $0.93 \%$ for a concentration of $4 \times 10^{-5} \mathrm{M}$. The results showed that the proposed method could be used for determining the iodate in samples of table salt.

Cho et al [12] have shown the possibility of utilising an unmodified office desktop ink jet printer to modify both $\mathrm{CD}$-Rs to form a number of different electrode designs. Using such an approach they showed that phospholipid films can be patterned with a lateral resolution of $50 \mu \mathrm{m}$. The authors projected that the approach could be effectively used for the commercial production of low-cost 
biosensors and electroanalytical devices. To demonstrate the possible applications of using an office inkjet printer for patterning the authors fabricated an iodine sensor by patterning a Au CD electrode array followed by printing phospholipid films across the electrodes. Initial results were not satisfactory because of the low conductivity of phospholipid films, but by using free software (GIMP, http://www.gimp.org) they were able to design a new pattern, covering the entire surface of a gold CD-R with 84 sets of interdigital gold microelectrodes configured in parallel. Each set consisted of four pairs of $200 \mu \mathrm{m}$ wide Au finger electrodes insulated from the connect pads at both ends; the whole sensor was produced by inkjet printing of an alkanethiolate monolayer with subsequent chemical etching. Current-voltage responses to different concentrations of iodine vapour were generally linear in the voltage range -2.0 to $+2.0 \mathrm{~V}$, indicating ohmic conduction behaviour in the phospholipid films. Measurement of the slopes of the currentvoltage curves showed a correlation between the conductance of the device and the iodine vapour concentration. The authors explained the change in conductivity in phospholipid films to be due the accumulation of $\mathrm{I}_{2}$ or $\mathrm{I}_{3}^{-}$in the head-head group region of the lipid bilayer.

Richter et al [13] have described a method of defining the electrode geometries via the laser printing of designs on wax paper and heat-transferring the toner onto the Au surface of the disc and etching of the Au layer away from the unprinted regions. The toner was then removed with a solvent. The unused electrode areas were then masked with varnish. Repetitive injections $(n=10)$ of a mixture containing iodide, ascorbic acid, dipyrone, and acetaminophen (20, 200, 500, and $100 \mu \mathrm{M})$, were found to give relative standard deviations of $2.9,4.5,6.1$, and $4.0 \%$, respectively. Detection limits $(\mathrm{S} / \mathrm{N}=3)$ were $0.1,0.5,3.1$, and $1.1 \mathrm{mM}$, respectively. 


\begin{tabular}{|c|c|c|c|c|c|c|c|c|c|}
\hline Analyte & $\begin{array}{l}\text { Electrode } \\
\text { Material }\end{array}$ & $\begin{array}{l}\text { Sample } \\
\text { Pre- } \\
\text { treatment }\end{array}$ & $\begin{array}{l}\text { Supporting } \\
\text { Electrolyte }\end{array}$ & $\begin{array}{l}\text { Measurement } \\
\text { Technique }\end{array}$ & $\begin{array}{l}\text { Linear } \\
\text { Range }\end{array}$ & $\begin{array}{l}\text { Detection } \\
\text { Limit }\end{array}$ & Sample(s) & Comments & Ref. \\
\hline $\mathrm{H}_{2} \mathrm{O}_{2}$ & $\mathrm{Ag}$ & -- & $\begin{array}{l}0.2 \mathrm{M} \mathrm{pH} 7.0 \\
\text { phosphate } \\
\text { buffer saline }\end{array}$ & Amperometry & $\begin{array}{l}10.0 \\
\mu \mathrm{M} \text { to } \\
22.5 \\
\mathrm{mM}\end{array}$ & $6 \mu \mathrm{M}$ & -- & $\begin{array}{l}\text { Electrochemi } \\
\text { cal } \\
\text { roughening } \\
\text { of electrode } \\
\text { surface by } \\
\text { oxidation- } \\
\text { reduction } \\
\text { voltammetric } \\
\text { cycles }\end{array}$ & {$[4,5]$} \\
\hline $\mathrm{H}_{2} \mathrm{O}_{2}$ & $\begin{array}{l}\text { Ag, } \\
\text { Verbatim } \\
\text { DVD-R }\end{array}$ & $\begin{array}{l}\text { Addition of } \\
\text { supporting } \\
\text { electrolyte }\end{array}$ & $\begin{array}{l}0.1 \mathrm{M} \mathrm{pH} 7.2 \\
\text { phosphate } \\
\text { buffer }\end{array}$ & Cyclic voltammetry & $\begin{array}{l}0.087- \\
3.41 \\
\mathrm{mM}\end{array}$ & $78.35 \mu \mathrm{M}$ & $\begin{array}{l}\text { Potable } \\
\text { water }\end{array}$ & -- & [75] \\
\hline $\mathrm{H}_{2} \mathrm{O}_{2}$ & $\begin{array}{l}\text { Au and } \mathrm{Au} \\
\mathrm{CD} \\
\text { modified } \\
\text { with } \\
\text { Prussian } \\
\text { Blue }\end{array}$ & $\begin{array}{l}\text { Milk sample } \\
\text { diluted with } \\
\text { water }\end{array}$ & $\begin{array}{l}\text { Diluted milk } \\
\text { sample }\end{array}$ & Cyclic voltammetry & $\overline{--}$ & $\overline{--}$ & Milk & $\begin{array}{l}\text { Voltammetric } \\
\text { electronic } \\
\text { tongue array. } \\
\mathrm{HCl}, \mathrm{KCl} \text {, } \\
\text { quinine and } \\
\text { sucrose also } \\
\text { investigated }\end{array}$ & [76] \\
\hline $\mathrm{H}_{2} \mathrm{O}_{2}$ & $\begin{array}{l}\text { Au CD } \\
\text { modified } \\
\text { with } \\
\text { Prussian } \\
\text { blue film }\end{array}$ & & $\begin{array}{l}0.1 \mathrm{M} \mathrm{pH} 5.3 \\
\text { phosphate } \\
\text { buffer }\end{array}$ & Amperometry & $\begin{array}{l}1.0 \mu \mathrm{M} \\
\text { to } 1.2 \\
\mathrm{mM}\end{array}$ & $0.4 \mu \mathrm{M}$ & $\overline{--}$ & $\begin{array}{l}\text { Prussian } \\
\text { blue film } \\
\text { formed } \\
\text { photochemic } \\
\text { ally from an } \\
\text { acidic } \\
\text { ferricyanide } \\
\text { solution }\end{array}$ & [78] \\
\hline Iodine & $\begin{array}{l}\text { Au modified } \\
\text { with an } \\
\text { alkanethiol } \\
\text { ate self- } \\
\text { assembled } \\
\text { monolayer }\end{array}$ & $\overline{--}$ & -- & Conductivity & $\begin{array}{l}10 \% \text { to } \\
100 \% \\
\text { saturat } \\
\text { ed } \\
\text { solutio } \\
\text { ns }\end{array}$ & $\overline{--}$ & $\overline{--}$ & $\begin{array}{l}\text { Electrodes } \\
\text { modified with } \\
\text { office inkjet } \\
\text { printer }\end{array}$ & [12] \\
\hline Iodine, & $\mathrm{Au}$ & $\ldots$ & Running & Capillary & & $0.1,0.5$, & $\overline{--}$ & Wall jet & [13] \\
\hline
\end{tabular}




\begin{tabular}{|c|c|c|c|c|c|c|c|c|c|}
\hline $\begin{array}{l}\text { ascorbic } \\
\text {, uric } \\
\text { acid } \\
\text { dipyron } \\
\text { e and } \\
\text { acetami } \\
\text { nophen }\end{array}$ & & & $\begin{array}{l}\text { buffer of } 20 \\
\text { mM boric } \\
\text { acid and } 12 \\
\text { mM sodium } \\
\text { hydroxide } \\
\text { (pH 9.2). } \\
\text { Cetyltrimethy } \\
\text { lammonium } \\
\text { hydroxide } \\
\text { (CTAH; } 0.2 \\
\text { mM) }\end{array}$ & $\begin{array}{l}\text { electrophoresis } \\
\text { amperometric } \\
\text { detection, single } \\
\text { electrode }(+0.75 \mathrm{~V}) \\
\text { and dual electrode } \\
(\mathrm{E} 1+1.0 \mathrm{~V}, \mathrm{E} 2+0.7 \mathrm{~V})\end{array}$ & & $\begin{array}{l}3.1, \text { and } \\
1.1 \mathrm{mM} \text { for } \\
\text { iodide, } \\
\text { ascorbic } \\
\text { acid, } \\
\text { dipyrone, } \\
\text { and } \\
\text { acetaminop } \\
\text { hen, } \\
\text { respectively }\end{array}$ & & configuration & \\
\hline Iodine & $\mathrm{Au} \mathrm{CD}$ & & & Amperometry, $+0.1 \mathrm{~V}$ & $\begin{array}{l}2 \times 10^{-5} \\
- \\
1.0 \times 10^{-} \\
{ }^{4} \mathrm{M}\end{array}$ & & Table salt & & {$[77]$} \\
\hline Iodine & $\mathrm{Au} \mathrm{CD}$ & $\begin{array}{l}\text { Electroche } \\
\text { mically } \\
\text { generated } \\
\text { iodine }\end{array}$ & $\begin{array}{l}0.5 \mathrm{M} \mathrm{KCl} \text { or } \\
\text { a } 1.0 \mathrm{M} \mathrm{Na} \\
\text { acetate } / 1.0 \\
\mathrm{M} \text { acetic acid } \\
\text { buffer } \\
\text { solutions }\end{array}$ & $\begin{array}{l}\text { Amperometry. Dual } \\
\text { band electrode cell } \\
\text { operated in generator } \\
\text { - collector model. } \mathrm{W} 1 \\
=0.5 \mathrm{~V}, \mathrm{~W} 2=0 \mathrm{~V} . \\
\text { flow rate }=0.7 \\
\mathrm{~mL} / \mathrm{min}\end{array}$ & & $\begin{array}{l}1 \mu \mathrm{M} \\
\text { thiosulphat } \\
\mathrm{e}\end{array}$ & -- & $\begin{array}{l}\text { Dual-in } \\
\text { series band } \\
\text { electrodes } \\
\text { thin layer } \\
\text { electrochemic } \\
\text { al cell. } \\
\text { Detection of } \\
\text { electrochemic } \\
\text { ally } \\
\text { generated } \\
\text { iodine by } \\
\text { thiosulphate } \\
\text { titration. }\end{array}$ & [79] \\
\hline $\begin{array}{l}\text { Iodide } \\
\text { and } \\
\text { Ascorbi } \\
\text { c Acid }\end{array}$ & $\mathrm{Au} \mathrm{CD}$ & -- & $\begin{array}{l}\text { Sodium } \\
\text { borate with } \\
0.02 \mathrm{mM} \\
\text { cetyltrimethy } \\
\text { lammonium } \\
\text { pH } 9.2\end{array}$ & $\begin{array}{l}\text { Amperometry, +0.9 V } \\
\text { (vs. Ag/AgCl). } \\
\text { Electrophoresis } \\
\text { separation voltage, } \\
4.0 \mathrm{kV}\end{array}$ & $\begin{array}{l}\text { Iodide } \\
2-30 \\
\mathrm{mM} ; \\
\text { ascorbi } \\
\mathrm{c} \text { acid } \\
10-50 \\
\mathrm{mM} \\
\end{array}$ & $\begin{array}{l}\text { Iodine } 0.5 \\
\mu \mathrm{M} \text { and } \\
\text { Ascorbic } \\
\text { Acid } 1.8 \\
\mu \mathrm{M}\end{array}$ & -- & $\begin{array}{l}\text { Electrophore } \\
\text { sis microchip } \\
\text { fabricated } \\
\text { from a laser } \\
\text { printed } \\
\text { double toner } \\
\text { layer (DTL) }\end{array}$ & [18] \\
\hline Glucose & $\mathrm{Ag}$ & $\begin{array}{l}15 \mu \mathrm{L} \text { of } \\
\text { blood }\end{array}$ & $\begin{array}{l}0.1 \mathrm{M} \mathrm{pH} 6.5 \\
\text { phosphate }\end{array}$ & Amperometry, $-0.5 \mathrm{~V}$ & $\begin{array}{l}0.5-13 \\
\mathrm{mM}\end{array}$ & $0.035 \mathrm{mM}$ & $\begin{array}{l}\text { Human } \\
\text { blood }\end{array}$ & $\begin{array}{l}\text { Direct } \\
\text { electrochemic }\end{array}$ & [69] \\
\hline
\end{tabular}




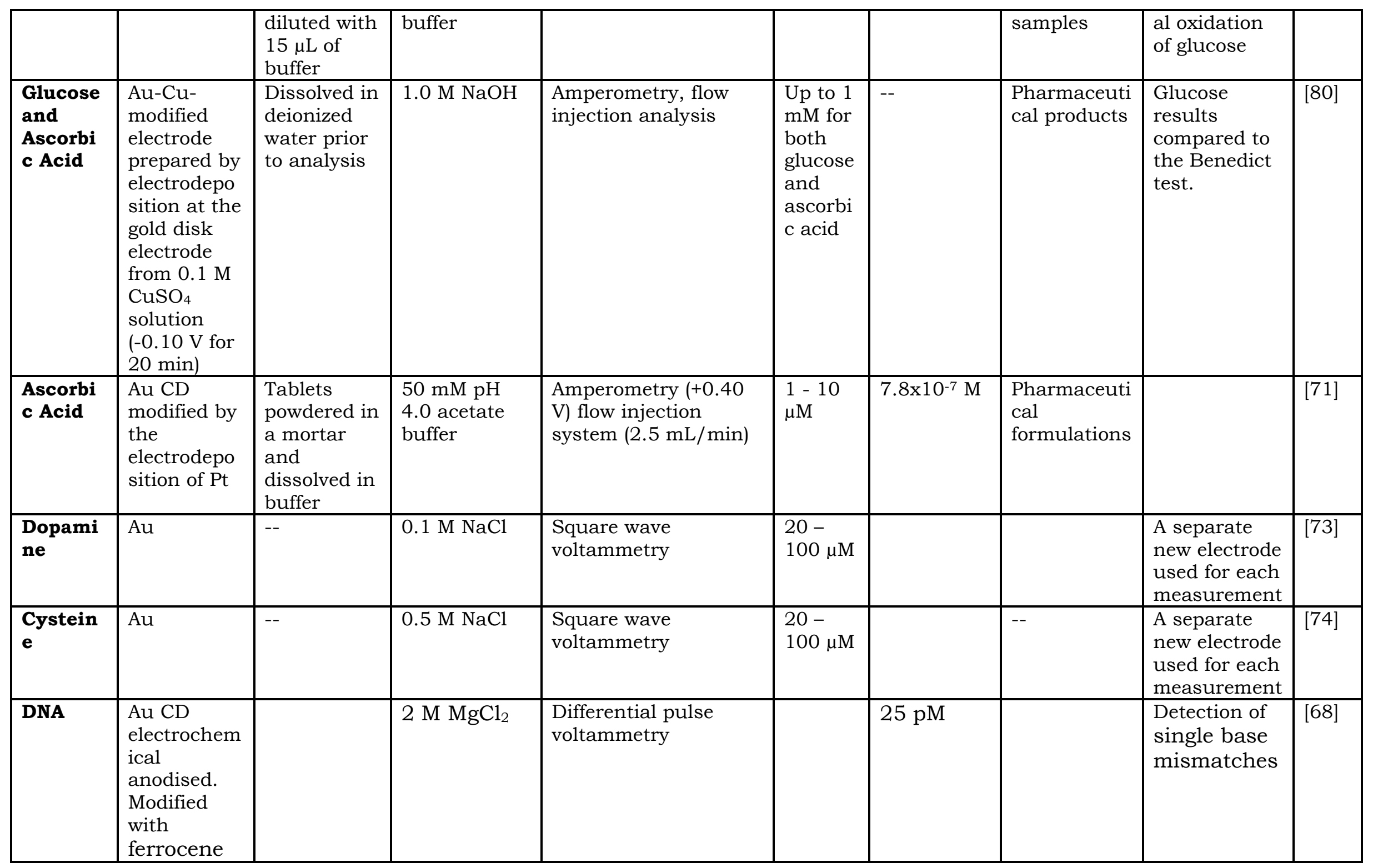




\begin{tabular}{|c|c|c|c|c|c|c|c|c|c|}
\hline & $\begin{array}{l}\text { carboxylic } \\
\text { acid } \\
\text { labelled } \\
\text { DNA }\end{array}$ & & & & & & & & \\
\hline $\begin{array}{l}\text { Dipyron } \\
\text { e }\end{array}$ & $\mathrm{Au}$ & - & $\begin{array}{l}0.1 \mathrm{M} \mathrm{pH} 4.7 \\
\text { acetate buffer }\end{array}$ & $\begin{array}{l}\text { Amperometry }(+0.800 \\
\text { V) flow injection } \\
\text { system (flow rate of } \\
83 \mu \mathrm{L} / \mathrm{min})\end{array}$ & & & -- & $\begin{array}{l}\text { Electrode } \\
\text { arrays } \\
\text { microfluidic } \\
\text { flow cells } \\
\text { fabricated by } \\
\text { printed toner } \\
\text { masks }\end{array}$ & [29] \\
\hline $\begin{array}{l}\text { Dipyron } \\
\text { e }\end{array}$ & $\mathrm{Au}$ & $\begin{array}{l}\text { Samples } \\
\text { dissolved in } \\
\text { phosphate } \\
\text { buffer }\end{array}$ & $\begin{array}{l}0.05 \mathrm{M} \mathrm{pH} 7 \\
\text { phosphate } \\
\text { buffer }\end{array}$ & $\begin{array}{l}\text { Amperometry }(+0.600 \\
\mathrm{V} v \text { s } \mathrm{Ag} / \mathrm{AgCl} \text { ) flow } \\
\text { cell (flow rate } 2 \\
\mathrm{~mL} / \mathrm{min})\end{array}$ & $\begin{array}{l}1.0 \mu \mathrm{M} \\
-10 \mu \mathrm{M}\end{array}$ & $0.1 \mu \mathrm{M}$ & $\begin{array}{l}\text { Commercial } \\
\text { pharmaceuti } \\
\text { cal tablets }\end{array}$ & $\begin{array}{l}\text { Good } \\
\text { agreement } \\
\text { with } \\
\text { iodometric } \\
\text { analysis. }\end{array}$ & {$[81]$} \\
\hline $\begin{array}{l}\text { Dipyron } \\
\text { e, } \\
\text { paracet } \\
\text { amol } \\
\text { and } \\
\text { nitrite }\end{array}$ & $\mathrm{Au}$ & $\begin{array}{l}\text { Tablets } \\
\text { crushed } \\
\text { and } \\
\text { dissolved in } \\
100 \mathrm{~mL} \text { of } \\
\text { deionized } \\
\text { water }\end{array}$ & $\begin{array}{l}0.1 \mathrm{M} \mathrm{pH} 4.7 \\
\text { acetate buffer }\end{array}$ & $\begin{array}{l}\text { Linear sweep } \\
\text { voltammetry }\end{array}$ & $\begin{array}{l}\text { Paracet } \\
\text { amol, } \\
0.3- \\
2.8 \\
\mathrm{mM} ; \\
\text { nitrite } \\
20- \\
100 \\
\mu \mathrm{M}, \\
\text { dipyron } \\
\text { e, up to } \\
1.2 \mathrm{mM}\end{array}$ & -- & $\begin{array}{l}\text { Pharmaceuti } \\
\text { cal tablet } \\
\text { formulations }\end{array}$ & $\begin{array}{l}\text { Ag glue } \\
\text { deposited on } \\
\text { the gold } \\
\text { surface used } \\
\text { as reference } \\
\text { electrode }\end{array}$ & [58] \\
\hline $\begin{array}{l}\text { Paracet } \\
\text { amol }\end{array}$ & $\begin{array}{l}\text { Au } \\
\text { electrode } \\
\text { modified by } \\
\text { drop } \\
\text { casting a } \\
\text { composite } \\
\text { consisting } \\
\text { of carbon } \\
\text { nanotubes }\end{array}$ & & $\begin{array}{l}0.1 \mathrm{M} \mathrm{pH} 9 \\
\text { phosphate } \\
\text { buffer. }\end{array}$ & $\begin{array}{l}\text { Differential pulse } \\
\text { voltammetry }\end{array}$ & $\begin{array}{l}0.5-80 \\
\mu \mathrm{M}\end{array}$ & $0.01 \mu \mathrm{M}$ & $\begin{array}{l}\text { Tablet, river } \\
\text { and waste } \\
\text { water } \\
\text { samples }\end{array}$ & & {$[82]$} \\
\hline
\end{tabular}




\begin{tabular}{|c|c|c|c|c|c|c|c|c|c|}
\hline & $\begin{array}{l}\text { and copper } \\
\text { nanoparticl } \\
\text { es }\end{array}$ & & & & & & & & \\
\hline $\begin{array}{l}\text { p- } \\
\text { Nitroph } \\
\text { enol }\end{array}$ & $\begin{array}{l}\text { Au } \\
\text { electrode } \\
\text { modified } \\
\text { with nano- } \\
\text { porous } \\
\mathrm{Hg} / \mathrm{Au} \\
\text { amalgam }\end{array}$ & -- & $\begin{array}{l}0.05 \mathrm{M} \mathrm{pH} 5 \\
\text { phosphate } \\
\text { buffer }\end{array}$ & $\begin{array}{l}\text { Square wave } \\
\text { voltammetry }\end{array}$ & $\begin{array}{l}5 \mu \mathrm{M}- \\
250 \mu \mathrm{M}\end{array}$ & $1 \mu \mathrm{M}$ & $\begin{array}{l}\text { River, tap } \\
\text { and sea } \\
\text { water }\end{array}$ & -- & [83] \\
\hline $\begin{array}{l}\text { Ciclopir } \\
\text { ox } \\
\text { olamine }\end{array}$ & $\begin{array}{l}\text { Au random } \\
\text { microarray }\end{array}$ & $\begin{array}{l}\text { Diluted in } \\
\text { buffer. }\end{array}$ & $\begin{array}{l}0.10 \mathrm{M} \mathrm{pH} \\
5.0 \text { Britton } \\
\text { Robinson } \\
\text { buffer. }\end{array}$ & $\begin{array}{l}\text { Amperometry, }+0.85 \\
\text { V vs. Ag/AgCl. }\end{array}$ & $\begin{array}{l}0.06 \\
\mathrm{mM}- \\
1.1 \mathrm{mM}\end{array}$ & $3 \mu \mathrm{M}$ & $\begin{array}{l}\text { Pharmaceuti } \\
\text { cal products }\end{array}$ & $\begin{array}{l}\text { Good } \\
\text { agreement } \\
\text { with those } \\
\text { found by } \\
\text { potentiometri } \\
\text { c titration } \\
\text { and the } \\
\text { labelled } \\
\text { values. }\end{array}$ & {$[18]$} \\
\hline $\begin{array}{l}\text { Terbutal } \\
\text { ine }\end{array}$ & $\begin{array}{l}\text { Au } \\
\text { electrode } \\
\text { drop coated } \\
\text { with } \\
\text { MWCNT in } \\
\text { DMF (1.0 } \\
\text { mg/mL). } \\
\text { Allowed to } \\
\text { dry at room } \\
\text { temperatur } \\
\text { e }\end{array}$ & & $\begin{array}{l}0.1 \mathrm{M} \mathrm{pH} 8.0 \\
\text { phosphate } \\
\text { buffer }(.086 \\
\mathrm{M} \mathrm{K}_{2} \mathrm{HPO}_{4} \\
\text { and } 0.014 \mathrm{M} \\
\left.\mathrm{NaH}_{2} \mathrm{PO}_{4}\right) .\end{array}$ & $\begin{array}{l}\text { Amperometry. Flow } \\
\text { electrochemical cell } \\
\text { with impingent jet. }\end{array}$ & $\begin{array}{l}3.0 \times 10^{-} \\
6 \text { to } \\
5.0 \times 10^{-} \\
{ }^{4} \mathrm{M}\end{array}$ & $5.8 \times 10^{-7} \mathrm{M}$ & $\begin{array}{l}\text { Commercial } \\
\text { pharmaceuti } \\
\text { cal syrup } \\
\text { samples }\end{array}$ & $\begin{array}{l}\text { Good } \\
\text { agreement } \\
\text { obtained with } \\
\text { high } \\
\text { performance } \\
\text { liquid } \\
\text { chromatogra } \\
\text { phy and } \\
\text { capillary } \\
\text { electrophores } \\
\text { is-tandem } \\
\text { mass } \\
\text { spectrometry. }\end{array}$ & {$[84]$} \\
\hline $\begin{array}{l}\text { Chlorpr } \\
\text { omazine }\end{array}$ & $\mathrm{Au}$ & $\begin{array}{l}\text { Formation } \\
\text { of a stable } \\
\text { cationic } \\
\text { radical by } \\
\text { electro- }\end{array}$ & $\begin{array}{l}\text { Electrochemi } \\
\text { cal oxidation } \\
\text { in } 0.1 \mathrm{M} \\
\mathrm{H}_{2} \mathrm{SO}_{4} \text {; } \\
\text { monitored in }\end{array}$ & $\begin{array}{l}\text { Spectroelectrochemist } \\
\text { ry and amperometry } \\
\text { in a flow cell }\end{array}$ & $\begin{array}{l}\text { Ampero } \\
\text { metry, } \\
3.3 \times 10^{-} \\
4- \\
2.0 \times 10^{-}\end{array}$ & $\begin{array}{l}7.6 \times 10^{-5} \\
\text { and } \\
4.1 \times 10^{-5} \mathrm{M} \\
\text { for the } \\
\text { electroche }\end{array}$ & $\begin{array}{l}\text { In pure form } \\
\text { or in } \\
\text { Amplictil } \\
\text { tablets }\end{array}$ & -- & {$[85]$} \\
\hline
\end{tabular}




\begin{tabular}{|c|c|c|c|c|c|c|c|c|c|}
\hline & & oxidation & $\begin{array}{l}\text { situ at } \lambda= \\
524 \mathrm{~nm} .\end{array}$ & & $\begin{array}{l}\mathrm{M} \text {; } \\
\text { Spectro } \\
\text { electroc } \\
\text { hemical } \\
\text { ly, } \\
1.6 \times 10^{-} \\
4- \\
2.0 \times 10^{-} \\
3 \mathrm{M}\end{array}$ & $\begin{array}{l}\text { mical and } \\
\text { spectropho } \\
\text { tometric } \\
\text { measureme } \\
\text { nts } \\
\text { respectively }\end{array}$ & & & \\
\hline $\begin{array}{l}\text { Promet } \\
\text { hazine }\end{array}$ & $\mathrm{Au}$ & $\begin{array}{l}\text { Formation } \\
\text { of a stable } \\
\text { cationic } \\
\text { radical by } \\
\text { electro- } \\
\text { oxidation }\end{array}$ & $\begin{array}{l}\text { Electrochemi } \\
\text { cal oxidation } \\
\text { in } 0.1 \mathrm{M} \\
\mathrm{H}_{2} \mathrm{SO}_{4} \\
+0.850 \mathrm{~V} \text {. } \\
\text { Monitored in } \\
\text { situ at } \lambda= \\
524 \mathrm{~nm} .\end{array}$ & $\begin{array}{l}\text { Spectroelectrochemist } \\
\text { ry and amperometry } \\
\text { in a flow cell, flow rate } \\
2.0 \mathrm{~mL} / \mathrm{min}\end{array}$ & $\begin{array}{l}1.0 \times 10^{-} \\
6- \\
5.0 \times 10^{-} \\
{ }^{3} \mathrm{M}\end{array}$ & $\begin{array}{l}1.3 \times 10^{-6} \\
\text { and } \\
3.0 \times 10^{-5} \mathrm{M} \\
\text { for } \\
\text { spectropho } \\
\text { tometric } \\
\text { and } \\
\text { electroche } \\
\text { mical } \\
\text { measureme } \\
\text { nts }\end{array}$ & $\begin{array}{l}\text { pure form or } \\
\text { in } \\
\text { pharmaceuti } \\
\text { cal } \\
\text { formulations }\end{array}$ & $\begin{array}{l}\text { The } \\
\text { Spectroelectr } \\
\text { ochemistry } \\
\text { approach } \\
\text { could } \\
\text { overcome } \\
\text { interferences } \\
\text { of } \\
\text { electroactive } \\
\text { compounds } \\
\text { such as } \\
\text { dipyrone } \\
\end{array}$ & {$[86]$} \\
\hline $\begin{array}{l}\text { o- } \\
\text { Tolidine }\end{array}$ & $\mathrm{Au}$ & $\overline{--}$ & $\begin{array}{l}0.125 \mathrm{M} \\
\text { acetic acid } \\
\text { and } 0.250 \mathrm{M} \\
\mathrm{HClO}_{4}, 0.800 \\
\mathrm{~V} . \text { Monitored } \\
\text { at } 438 \mathrm{~nm} \text {. }\end{array}$ & $\begin{array}{l}\text { Spectroelectrochemic } \\
\text { al dual electrode flow } \\
\text { cell. } 1.84 \mathrm{~mL} / \mathrm{min} .\end{array}$ & $\begin{array}{l}1.12 \times 1 \\
0^{-5}- \\
1.12 \times 1 \\
0^{-4} \mathrm{M}\end{array}$ & $\overline{--}$ & -- & $\begin{array}{l}\text { Cell can fit in } \\
\text { standard } \\
\text { spectrophoto } \\
\text { metric } \\
\text { cuvette with } \\
1.0 \mathrm{~cm} \\
\text { optical path }\end{array}$ & {$[87]$} \\
\hline $\begin{array}{l}\text { Paraqua } \\
t\end{array}$ & $\mathrm{Au} C D$ & $\begin{array}{l}\mathrm{Na}_{2} \mathrm{SO}_{4} \\
\text { dissolved } \\
\text { directly into } \\
\text { the water or } \\
\text { tea sample } \\
\text { and } \\
\text { degassed } \\
\text { with } \mathrm{N}_{2}\end{array}$ & $0.1 \mathrm{M} \mathrm{Na}_{2} \mathrm{SO}_{4}$ & $\begin{array}{l}\text { Square wave } \\
\text { voltammetry }\end{array}$ & $\begin{array}{l}2.8 \times 10^{-} \\
5- \\
27.7 \times 1 \\
0^{-5} \mathrm{M}\end{array}$ & $\begin{array}{l}\text { Natural } \\
\text { water, } 21 \\
\mu \mathrm{g} / \mathrm{L}\end{array}$ & $\begin{array}{l}\text { Natural } \\
\text { water and } \\
\text { commercial } \\
\text { tea samples }\end{array}$ & & {$[88]$} \\
\hline Thrombi & $\mathrm{Au}$ & $\mathrm{Au}$ & & Impedance & $1.0-$ & & -- & Biosensor & {$[67]$} \\
\hline
\end{tabular}




\begin{tabular}{|c|c|c|c|}
\hline $\mathbf{n}$ & \begin{tabular}{|l} 
electrode \\
modified \\
with \\
cysteamine, \\
glutaraldeh \\
yde, \\
streptavidin \\
and \\
thrombin- \\
binding \\
aptamer.
\end{tabular} & $\begin{array}{l}\text { spectroscopy, } 100 \\
\mathrm{mHz} \text { to } 200 \mathrm{kHz}\end{array}$ & $100 \mathrm{nM}$ \\
\hline
\end{tabular}

Table 2. Application of CD and DVD electrodes for the determination of oxidising agents and organic compounds 


\section{Conclusions}

The fabrication of electrodes manufactured from DVDs and CDs has been shown to be versatile, highly reproducible and economic. The simplicity of construction and low cost of planar Au and Ag electrodes allows their use as disposable devices. This offers a number of possible advantages over problems such as electrode fouling and carryover. A number of studies have shown the possibility of being able to modify the exposed metal layer using readily available office printers $[7,10,76]$ or similar techniques [73] or chemically to form self-assemble monolayers [32] of for the addition for functional groups [33]. Beyond the scope of this review, reports have shown the possibility of utilising CDs and DVDs for both sample preparation as well as quantification using approaches such as surface plasma resonance [89], centrifugal microfluidics or so called 'lab-on-a-disc' devices [90-95], DNA microarrays [96]. Their application in the exploitation of solar energy [97] and the development of batteries [98] has also been reported.

\section{Acknowledgements}

I like to thank my fellow researchers whose work is reviewed here. I am grateful to the University of the West England.

\section{References}

[1] D.C. Kirkpatrick, C. Antwi, R. Scott Martin, Use of Recordable Compact Discs to Fabricate Electrodes for Microchip-based Analysis Systems, Anal. Methods, 2 (2010) 811-816.

[2] J.A. Cope, The physics of the compact disc, Phys. Educ. 28 (1993) 15-21.

[3] K.A. Schouhammer Immink, The Compact Disc Story, J. Audio Eng. Soc. 46 (1998) 458-465.

[4] W. Lain, L. Wang, Y. Song, H. Yuan, S. Zhao, P. Li, L. Chen, A hydrogen peroxide sensor based on electrochemically roughened silver electrodes, Electrochim. Acta 54 (2009) 4334-4339.

[5] Y. Wenn, A.-J. Lin, H.-F. Chen, Y.-Z. Jiao, H.-F. Yang, From DVD to dendritic nanostructure silver electrode for hydrogen peroxide detection, Biosensor. Bioelectron. 41 (2013) 857-861.

[6] J. Fernández-Dorado, J. Hernández-Andrés, E.M. Valero, J.L. Nieves, J. Romero, A simple experiment to distinguish between replicated and 
duplicated compact discs using Fraunhofer diffraction, Am. J. Phys. 76 (2008) 1137-1140.

[7] K.C. Honeychurch, Underpotential Deposition of Lead At Silver Electrodes Manufactured From Compact Discs and Its Determination In Environmental Water Samples, Ad. Anal. Chem. 3A (2013) 28-33.

[8] H.-Z. Yu, A.W. Rowe, D.M. Waugh, Templated Electrochemical Deposition of Zirconia Thin Films on "Recordable CDs", Anal. Chem. 74 (2002) 5742-5747.

[9] L. Angnes, E.M. Richter, M.A. Augelli, G.H. Kume, Gold Electrodes from Recordable CDs, Anal. Chem. 72 (2000) 5503-5506.

[10] Y. Wenn, A.-J. Lin, H.-F. Chen, Y.-Z. Jiao, H.-F. Yang, From DVD to dendritic nanostructure silver electrode for hydrogen peroxide detection, Biosens. Bioelectron. 41 (2013) 857-861.

[11] H.-Z. Yu, New chemistry on old CDs, Chem. Commun. 23 (2004) 2633-2636.

[12] H. Cho, M. (Ash) Parameswaran, H.-Z. Yu, Fabrication of microsensors using unmodified office inkjet printers, Sensor Actuat. B-Chem. 123 (2007) 749756.

[13] E.M. Richter, J.A.F. da Silva, I.G.R. Gutz, C.L. do Lago, L. Angnes, Disposable twin gold electrodes for amperometric detection in capillary electrophoresis, Electrophoresis 25 (2004) 2965-2969.

[14] D. Daniel, I.G.R. Gutz, Electronic micropipettor: A versatile fluid propulsion and injection device for micro-flow analysis, Anal. Chim. Acta 571 (2006) 218-227.

[15] Y. Li, P.C.H. Li, M. (Ash) Parameswaran, H.-Z. Yu, Inkjet Printed Electrode Arrays for Potential Modulation of DNA Self-Assembled Monolayers on Gold, Anal. Chem. 80 (2008) 8814-8821.

[16] J.J. La Clair, M.D. Burkart, Molecular screening on a compact disc, Org. Biomol. Chem. (2003) 1 3244-3249.

[17] E.M. Richter, R.A.A. Munoz, M. Bertotti, L. Angnes, Heat-transference of toner masks onto conductive substrates: A rapid and easy way to produce microelectrode ensembles, Electrochem. Commun. 9 (2007) 1091-1096.

[18] D. Daniel, I.G.R. Gutz, Microfluidic cell with a $\mathrm{TiO}_{2}$-modified gold electrode irradiated by an UV-LED for in situ photocatalytic decomposition of organic matter and its potentiality for voltammetric analysis of metal ions, Electrochem. Commun. 9 (2007) 522-528.

[19] A.P. Ruas de Souza, F.S. Felix, P.S. Castro, L. Angnes, M. Bertotti, Gold random microarrays: design, characterization and amperometric determination of ciclopirox olamine in pharmaceutical products, Anal. Methods, 8 (2016) 1078-1083.

[20] C.K. Tanga, A. Vazea, J.F. Rusling, Fabrication of immunosensor microwell arrays from gold compact discs for detection of cancer biomarker proteins, Lab Chip, 12 (2012) 281-286.

[21] W.K. Tomazelli Coltro, J.A. Fracassi da Silva, H.D. Torres da Silva, E.M. Richter, R. Furlan, L. Angnes, C. L. do Lago, L.H. Mazo, E. Carrilho, Electrophoresis microchip fabricated by a direct-printing process with endchannel amperometric detection, Electrophoresis 25 (2004) 3832-3839.

[22] T.R.L.C. Paixão, E.M. Richter, J.G.A. Brito-Neto, M. Bertotti, Fabrication of a new generator-collector electrochemical micro-device: Characterization and applications, Electrochem. Commun. 8 (2006) 9-14.

[23] T.R.L.C. Paixão, E.M. Richter, J.G.A. Brito-Neto, M. Bertotti, The use of a new twin-electrode thin-layer cell to the study of homogeneous processes coupled to electrode reactions, J. Electroanal. Chem. 596 (2006) 101-108. 
[24] K.C. Honeychurch, Screen-printed electrochemical sensors and biosensors for monitoring metal pollutants. Insciences J. 2 (2012) 1-51.

[25] G. Billon, C.M.G. van den Berg, Gold and Silver Micro-Wire Electrodes for Trace Analysis of Metals, Electroanalysis 2004, 16, 1583-1591.

[26] E.M. Richter, D.P. de Jesus, C.A. Neves, C.L. do Lago, L. Angnes, Aplicações Eletroanaliticas Com Eletrodos De Prata Confeccionados A Partir De CDs Graváveis, Quim. Nova, 26 (2003) 839-843.

[27] R.G. Compton, C.E. Banks, Understanding Voltammetry, 2nd edition, 2011, Imperial College Press.

[28] C. Maynard, K.C. Honeychurch, Amperometric Determination of Hydrogen Peroxide at a Silver Electrode Fabricated from a Recycled Compact Disc, Ad. Anal. Chem. 5 (2015) 25-30.

[29] D. Daniel, I. Gebhardt R. Gutz, Quick production of gold electrode sets or arrays and of microfluidic flow cells based on heat transfer of laser printed toner masks onto compact discs, Electrochem. Comm. 5 (2003) 782-786.

[30] T. L. Ferreira, T.R.L.C. Paixao, E.M. Richter, O.A. El Seoud, M. Bertotti,Use of Microdevices To Determine the Diffusion Coefficient of Electrochemically Generated Species: Application to Binary Solvent Mixtures and Micellar Solutions, J. Phys. Chem. B 111 (2007) 12478-12484.

[31] A. Walcarius, E. Sibottier, M. Etienne, J. Ghanbaja, Electrochemically assisted self-assembly of mesoporous silica thin films, Nat. Mater. 6 (2007) 602-608.

[32] H.-Z. Yu, Self-Assembly on "Recordable CDs", Anal. Chem. 73 (2001) 47434747.

[33] F. Matemadombo, P. Westbroek, T. Nyokong, K. Ozoemena, K. De Clerck, P. KiekensImmobilization of tetra-amine substituted metallophthalocyanines at gold surfaces modified with mercaptopropionic acid or DTSP-SAMs, Electrochim. Acta 52 (2007) 2024-2031.

[34] E. Sibottier, S. Sayen, F. Gaboriaud, A. Walcarius, Factors Affecting the Preparation and Properties of Electrodeposited Silica Thin Films Functionalized with Amine or Thiol Groups, Langmuir 22 (2006) 8366-8373.

[35] L.F Ferreira, J.F.C Boodts, A.G. Brito-Madurro, J.M. Madurro, Gold electrodes modified with poly(4-aminophenol): incorporation of nitrogenated bases and an oligonucleotide, Polym. Int. 57 (2008) 644-650.

[36] M.V. Foguel, G.P. dos Santos, A.A.P. Ferreira, M. Magnani, M. Mascini, P. Skladal, A.V. Benedetti,H. Yamanaka, Comparison of Gold CD-R Types as Electrochemical Device and as Platform for Biosensors, J. Braz. Chem. Soc. 27 (2016) 650-662.

[37] F. Vydra, K. Štulik, E. Julakova, Electrochemical Stripping Analysis, Ellis Horwood Ltd, 1977, Chichester.

[38] J. Wang, Stripping Analysis, VCH, Deerfield Beach, FL 1985.

[39] H. Channaa, P. Surmann, Voltammetric analysis of N-containing drugs using the hanging galinstan drop electrode (HGDE), Pharmazie, 64 (2009) 161-165.

[40] F. Arduini, J.Q. Calvo, A. Amine, G. Palleschi, D. Moscone, Bismuthmodified electrodes for lead detection. TrAC, 29 (2010) 1295-1304.

[41] I. Svancara, C. Prior, S.B. Hocevar, J. Wang, A Decade with Bismuth-Based Electrodes in Electroanalysis. Electroanalysis, 22 (2010) 1405-1420.

[42] C. Kokkinos, A. Economou, Stripping at Bismuth-Based Electrodes. Curr. Anal. Chem. 4 (2008) 183-190.

[43] A. Bobrowski, M. Putek, J. Zarebski, Antimony Film Electrode Prepared In Situ in Hydrogen Potassium Tartrate in Anodic Stripping Voltammetric Trace 
Detection of $\mathrm{Cd}(\mathrm{II}), \mathrm{Pb}(\mathrm{II}), \mathrm{Zn}(\mathrm{II}), \mathrm{Tl}(\mathrm{I}), \mathrm{In}(\mathrm{III})$ and $\mathrm{Cu}(\mathrm{II})$, Electroanalysis, 24 (2012) 1071-1078.

[44] F.W. Campbell, R.G. Compton, Contrasting Underpotential Depositions of Lead and Cadmium on Silver Macroelectrodes and Silver Nanoparticle Electrode Arrays, Int. J. Electrochem. Sci., 5 (2010) 407-413.

[45] E.M. Richter, J.J. Pedrotti, L. Angnes, Square-Wave Quantification of Lead in Rainwater with Disposable Gold Electrodes without Removal of Dissolved Oxygen, Electroanalysis 15 (2003) 1871-1877.

[46] C. Fernandes Pereira, F. Barbieri Gonzaga, A.M. Guaritá-Santos, J. Rodrigues SouzaDe, Determination of Se(IV) by anodic stripping voltammetry using gold electrodes made from recordable CDs, Talanta 69 (2006) 877881.

[47] C.M. Watson, D.J. Dwyner, J.C. Andle, A.E. Bruce, M.R.M. Bruce, Stripping Analyses of Mercury Using Gold Electrodes: Irreversible Adsorption of Mercury, Anal. Chem. 71 (1999) 3181-3186.

[48] M.-C. Radulescu, A.F. Danet, Mercury Determination in Fish Samples by Chronopotentiometric Stripping Analysis Using Gold Electrodes Prepared from Recordable CDs, Sensors 8 (2008) 7157-7171.

[49] M. Antonio Augelli, R.A. Abarza Munoz, E.M. Richter, A. Gouveia Jr, L. Angnes, Chronopotentiometric Stripping Analysis Using Gold Electrodes, an Efficient Technique for Mercury Quantification in Natural Waters, Electroanalysis 17 (2005) 755-761.

[50] E.M. Richter, M.A. Augelli, S. Magarotto, L. Angnes, Compact Disks, a New Source for Gold Electrodes. Application to the Quantification of Copper by PSA, Electroanalysis 13 (2001) 760-764.

[51] P. Westbroek, J. De Strycker, P. Dubruel, E. Temmerman, E.H. Schacht, Flow-Through Cell for On-Line, Amperometric Determination of Ce(IV) during Polymerization Reactions, Anal. Chem. 74 (2002) 915-920.

[52] D. Daniel, I.G.R. Gutz, Microfluidic cells with interdigitated array gold electrodes: Fabrication and electrochemical characterization, Talanta 68 (2005) 429-436.

[53] A.L.B. Baccaro, I.G.R. Gutz, Quick cold preparation of TiO2 nanolayers on gold from P25 suspensions-film structure, voltammetric behavior and photocatalytic performance for the oxidation of EDTA under UVA-LED irradiation, Electrochim. Acta 214 (2016) 295-306.

[54] R.A.A. Munoza, F.S. Felix, M.A. Augelli, T. Pavesi, L. Angnes, Fast ultrasound-assisted treatment of urine samples for chronopotentiometric stripping determination of mercury at gold film electrodes, Anal. Chim. Acta 571 (2006) 93-98.

[55] M.A. Augelli, R.A.A. Munoz, E.M. Richter, M.I. Cantagallo, L. Angnes, Analytical procedure for total mercury determination in fishes and shrimps by chronopotentiometric stripping analysis at gold film electrodes after microwave digestion, Food Chem. 101 (2007) 579-584.

[56] R.A.A. Munoz, P.V. Oliveira, L. Angnes, Combination of ultrasonic extraction and stripping analysis: An effective and reliable way for the determination of $\mathrm{Cu}$ and $\mathrm{Pb}$ in lubricating oils, Talanta 68 (2006) 850-856.

[57] N.I. Cristea, M.-C. Radulescu, R. Ciomartan, Mercury Determination in Fish Samples by Flow Injection Using Gold Electrodes Made from CD-R's, Rev. Chim. (Bucharest), 62 (2011) 951-957.

[58] H.E.A. Ferreira, D. Daniel, M. Bertotti, E.M. Richter, A Novel Disposable Electrochemical Microcell: Construction and Characterization, J. Braz. Chem. Soc. 19 (2008) 1538-1545. 
[59] R.A.B. da Silva, Edimar G.N. de Almeida, A.C. Rabelo, A.T.C. da Silva, L.F. Ferreira, E.M. Richter, Three Electrode Electrochemical Microfluidic Cell: Construction and Characterization, J. Braz. Chem. Soc. 20 (2009) 12351241.

[60] A. Walcarius, E. Sibottier, Electrochemically-Induced Deposition of AmineFunctionalized Silica Films on Gold Electrodes and Application to $\mathrm{Cu}$ (II) Detection in (Hydro)Alcoholic Medium, Electroanalysis 17 (2005) 1716-1726.

[61] F. Barbieri Gonzaga, C. Fernandes Pereira, A. Jose Moraes Guarita-Santos, J. Rodrigues Souza De, Development of an Automatic Electrochemical System for Differential Pulse Amperometry and Its Application for Se(IV) Determination, Electroanalysis 17 (2005) 2084-2089.

[62] R.A.A. Munoz, M. Kolbe, R.C. Siloto, P.V. Oliveira, L. Angnes, UltrasoundAssisted Treatment of Coconut Water Samples for Potentiometric Stripping Determination of Zinc, J. Braz. Chem. Soc. 18 (2007) 410-415.

[63] R.A.A. Munoz, C.S. Silva, P.R.M. Correia, P.V. Oliveira, L. Angnes, Potentiometric Stripping Analysis for Simultaneous Determination of Copper and Lead in Lubricating Oils, After Total Digestion in a Focused MicrowaveAssisted Oven, Microchim. Acta 149, (2005) 199-204.

[64] R.A.A. Munoz, P.R.M. Correia, A.N. Nascimento, C.S. Silva, P.V. Oliveira, L. Angnes, Electroanalysis of Crude Oil and Petroleum-Based Fuel for Trace Metals: Evaluation of Different Microwave-Assisted Sample Decompositions and Stripping Techniques, Energy \& Fuels 21 (2007) 295-302.

[65] M.V. Foguel, G.P. dos Santos, A. Aparecido Pupim Ferreira, H. Yamanaka, A. Vicente Benedetti, Amperometric Immunosensor for Chagas' Disease Using Gold CD-R Transducer, Electroanalysis 23 (2011) 2555-2561.

[66] A. Aparecido Pupim Ferreira, C. Venturini Uliana, M. de Souza Castilho, N. Canaverolo Pesquero, M.V. Foguel, G. Pilon dos Santos, C. Sadao Fugivara, A. Vicente Benedetti, H. Yamanaka (2013). Amperometric Biosensor for Diagnosis of Disease, State of the Art in Biosensors - Environmental and Medical Applications, T. Rinken (Ed.), ISBN: 978-953-51-1035-4, InTech, DOI: $\quad 10.5772 / 53656 . \quad$ Available from: http:/ /www.intechopen.com/books / state-of-the-art-in-biosensorsenvironmental-and-medical-applications/amperometric-biosensor-fordiagnosis-of-disease

[67] D. Frense, S. Kang, K. Schieke, P. Reich, A. Barthel, U. Pliquett, T. Nacke, C. Brian, D. Beckmann, Label-free impedimetric biosensor for thrombin using the thrombin-binding aptamer as receptor, XV Int. Conf. on Electrical BioImpedance \& XIV Conf. on Electrical Impedance Tomography, J. Phys.: Conf. Ser. 434 (2013) 012091.

[68] L.E. Ahangar, M.A. Mehrgardi, Nanoporous gold electrode as a platform for the construction of an electrochemical DNA hybridization biosensor, Biosensor Bioelectron. 38 (2012) 252-257.

[69] Y. Chen, L. Liu, M. Wang, C. Wang, X. Hu, G. Wang, Self-made nonenzymatic silver electrode from recordable CDs for fast detection of glucose in blood, Sensor Actuat. B-Chem. 177 (2013) 555-561.

[70] H.F. Cui, J.S. Ye, W.D. Zhang, C.M. Li, J.H.T. Luong, F.S. Sheu, Selective and sensitive electrochemical detection of glucose in neutral solution using platinum-lead alloy nanoparticle/carbon nanotube nanocomposites, Anal. Chim. Acta 594 (2007) 175-183.

[71] R.A.A. Muñoz, R. Camargo Matos, L. Angnes, Gold electrodes from compact discs modified with platinum for amperometric determination of ascorbic acid in pharmaceutical formulations, Talanta 55 (2001) 855-860. 
[72] M. Latino, D. Aloisio, N. Donato, G. Neri, Development of Sensing Transducers on Compact Disc Substrates in D. Compagnone, F. Baldini, C. Di Natale, G. Betta, P. Siciliano (Ed.), Sensors, Proceedings of the Second National Conference on Sensors, Rome 19-21 February, 2014, Volume 319 of the series Lecture Notes in Electrical Engineering pp. 187-190, Springer International Publishing Switzerland.

[73] P. Pessoa de Santana, I.M. Ferreira de Oliveira, E. Piccin, Evaluation of using xurography as a new technique for the fabrication of disposable gold electrodes with highly reproducible areas, Electrochem. Commun. 16 (2012) 96-99.

[74] D. Lowinsohn, E.M. Richter, L. Angnes, M. Bertotti, Disposable Gold Electrodes with Reproducible Area Using Recordable CDs and Toner Masks, Electroanalysis 18 (2006) 89-94.

[75] M. Shafei, K.C. Honeychurch, Voltammetric behaviour of hydrogen peroxide at a silver electrode fabricated from a rewritable digital versatile disc (DVD) and its determination in water samples, Anal. Methods, 5 (2013) 6631-6636.

[76] T.R.L.C. Paixão, M. Bertotti, Fabrication of disposable voltammetric electronic tongues by using Prussian Blue films electrodeposited onto CD-R gold surfaces and recognition of milk adulteration, Sensor Actuat. B-Chem. 137 (2009) 266-273.

[77] C.A. Lindino, L. de Lima Pelaquim, M.D. Previatto, Determinação de iodato em sal culinário com técnica amperométrica, Revista Varia Scientia, 6 (2007) 51-59.

[78] Y.-L. Hu, J.-H. Yuan, W. Chen, K. Wang, X.-H. Xia, Photochemical synthesis of Prussian blue film from an acidic ferricyanide solution and application, Electrochem. Commun. 7 (2005) 1252-1256.

[79] T.R.L.C. Paixão, R.C. Matos, M. Bertotti, Design and characterisation of a thin-layered dual-band electrochemical cell, Electrochim. Acta 48 (2003) 691698.

[80] T.R.L.C. Paixão, R.C. Matos, M. Bertotti, Development of a Dual-Band Amperometric Detector for Determination of Ascorbic Acid and Glucose, Electroanalysis 15 (2003) 1884-1889.

[81] R.A.A. Munoz, R.C. Matos, L. Angnes, Amperometric Determination of Dipyrone in Pharmaceutical Formulations with a Flow Cell Containing Gold Electrodes From Recordable Compact Discs, J. Pharm. Sci. 90 (2001) 19721977.

[82] L. Daneshvar, G.H. Rounaghi, S. Tarahomi, Voltammetric paracetamol sensor using a gold electrode made from a digital versatile disc chip and modified with a hybrid material consisting of carbon nanotubes and copper nanoparticles, Microchim. Acta (2016) 183 3001-3007.

[83] F. Afzali, M.H.A. Zavar, G. Rounaghi, N. Ashraf, Gold digital versatile disc platform modified with nano-porous mercury/gold amalgam as a solid-state disposable electrochemical sensor for detection of para-nitrophenol, Electrochim. Acta 209 (2016) 654-660.

[84] F.S. Felix, D. Daniel, J.R. Matos, C. Lucio do Lago, L. Angnes, Fast analysis of terbutaline in pharmaceuticals using multi-walled nanotubes modified electrodes from recordable compact disc, Anal. Chim. Acta 928 (2016) 32-38.

[85] D. Daniel, I.G.R. Gutz, Spectroelectrochemical determination of chlorpromazine hydrochloride by flow-injection analysis, J. Pharm. Biomed. Anal. 37 (2005) 281-286. 
[86] D. Daniel, I.G.R. Gutz, Flow injection spectroelectroanalytical method for the determination of promethazine hydrochloride in pharmaceutical preparations, Anal. Chim. Acta 494 (2003) 215-224.

[87] D. Daniel, I.G.R. Gutz, Long-Optical-Path Thin-Layer Spectroelectrochemical Flow Cell with Inexpensive Gold Electrodes, Electroanalysis 13 (2001) 681685.

[88] D. De Souza, L. Codognoto, S.A.S. Machado, L.A. Avaca, Electroanalytical Determination of the Herbicide, Paraquat in Natural Water and Commercial Tea Samples with Gold Electrodes Obtained from Recordable Compact Disc, Anal. Lett. 38 (2005) 331-341.

[89] B.K. Singh, A.C. Hillier, Surface Plasmon Resonance Imaging of Biomolecular Interactions on a Grating-Based Sensor Array, Anal. Chem. 78 (2006) 2009-2018.

[90] G. Jia, K.-S. Maa, J. Kima, J.V. Zoval, R. Peytavi, M.G. Bergeron, M.J. Madoua, Dynamic automated DNA hybridization on a CD (compact disc) fluidic platform, Sens. Actuator B-Chem. 114 (2006) 173-181.

[91[ M.W.L. Watson, M. Abdelgawad, G. Ye, N. Yonson, J. Trottier, A.R. Wheeler, Microcontact Printing-Based Fabrication of Digital Microfluidic Devices, Anal. Chem. 78 (2006) 7877-7885.

[92] N. Honda, U. Lindberg, P. Andersson, S. Hoffmann, H. Takei, Simultaneous Multiple Immunoassays in a Compact Disc-Shaped Microfluidic Device Based on Centrifugal Force, Clin. Chem. 51 (2005) 1955-1961.

[93] S. Lai, S. Wang, J. Luo, L.J. Lee, S.-T. Yang, M.J. Madou, Design of a Compact Disk-like Microfluidic Platform for Enzyme-Linked Immunosorbent Assay, Anal. Chem. 76 (2004) 1832-1837.

[94] J.V. Zoval, M.J. Madou, Centrifuge-based Fluidic Platforms, Proc. IEEE 92 (2004) 140-153.

[95] J. Gilmore, M. Islam, R. Martinez-Duarte, Challenges in the Use of Compact Disc-Based Centrifugal Microfluidics for Healthcare Diagnostics at the Extreme Point of Care, Micromachines 7 (2016) 52.

[96] S. Morais, R. Marco-Moles, R. Puchades, A. Maquieira, DNA microarraying on compact disc surfaces. Application to the analysis of single nucleotide polymorphisms in Plum pox virus, Chem. Commun. 2006 (2006) 2368-2370.

[97] L.J. Venturini da Silva, E.L. Foletto, L.S. Dorneles, D. S. Paz, T.S. Frantz, A. Günde, $\mathrm{ZnO}$ electrodeposition onto gold from recordable compact discs and its use as photocatalyst under solar irradiation, Braz. J. Chem. Eng. 30 (2013) 155-158.

[98] M. Hantezadeh, S. Rashid-Nadimi, Fabrication of a flat $\mathrm{V}^{3+} / \mathrm{Fe}^{3+}$ redox microbattery from gold compact disk using drilling technique, J. Power Sources 305 (2016) 144-150. 